\title{
National and international R\&D support programmes and technology scouting in European small and medium enterprises
}

\begin{tabular}{|r|l|}
\hline Journal: & Journal of Science and Technology Policy Management \\
\hline Manuscript ID & JSTPM-10-2019-0091.R2 \\
\hline Manuscript Type: & Research Paper \\
\hline Keywords: & $\begin{array}{l}\text { Technology scouting, Behavioural additionality, External knowledge } \\
\text { search, European SMEs, copula-based endogenous switching model }\end{array}$ \\
\hline \multicolumn{2}{|l}{} \\
\hline
\end{tabular}




\title{
National and international R\&D support programmes and technology scouting in European small and medium enterprises
}

\begin{abstract}
Purpose: This study evaluates the effectiveness of national and international R\&D support programmes on firms' technology scouting, defined as firms' use of external knowledge sources.

Design/methodology/approach: Drawing on a unique dataset on R\&D support programmes for small and medium-sized enterprises (SMEs) operating in both manufacturing and service sectors across 28 European countries, this study reports treatment effects estimated by a copulabased endogenous switching model, which takes into account unobserved firm heterogeneity. Findings: Empirical results indicate that R\&D support programmes have heterogeneous effects on technology scouting. In particular, a crowding out effect arises in the case of informal sources of external knowledge, while additional effects are reported for formal, strategic sources.

Practical implications: For informal sources of external knowledge, a random distribution of R\&D measures would have a substantially larger effect rather than using current selection criteria.

Originality/value: This is among first studies to explore the policy effects on technology scouting applying a copula-based endogenous switching model. Most cross-sectional empirical studies employ matching estimators, although their main disadvantage is the selection on observables.
\end{abstract}

Keywords: Technology scouting, Behavioural additionality; External knowledge search, European SMEs, copula-based endogenous switching model 


\section{Introduction}

Innovation policy has taken centre stage among policy makers in the European Union (EU) (Edler et al., 2012). A new EU strategy for economic growth and employment - Europe 2020 - defines one of its priorities as a sustainable growth through knowledge and innovation (European Commission, 2010). To foster research and innovation-led growth, the European Commission designed Horizon 2020, the 2014-2020 Framework Programmes for Research and Technological Development (CLORA, 2013). Innovation activities supported by Horizon 2020 encompass not only traditional, technological (product and process) innovations but also nontechnological (marketing and organisational) innovations and a demand-driven innovation (European Commission, 2013a).

Another relevant feature of Horizon 2020 is attention dedicated to small and mediumsized enterprises (SMEs), through policy instruments that will aim to support development, growth and internationalization of SMEs (European Commission, 2013b). Small and mediumsized enterprises are the engine of growth in the European economy, contributing to employment with 66.5 per cent of all European jobs in 2012 and gross value added at 57.6 per cent (European Commission, 2013b). Innovation is one of the critical activities through which small and medium sized enterprises contribute to increased employment, economic growth and development.

Policy makers not only recognize the importance of innovation and its public support, but increasingly recognize the relevance of evaluating the impact of support measures (Dimos and Pugh, 2016; Edler et al., 2012; Gök and Edler, 2012). Consequently, policy makers and scholars are interested in evaluating the effectiveness of public subsidies, that is, if public support enhances firms' innovation activities. Evaluation of public innovation support attempts to answer this question through qualitative evaluation (including case studies and interviews) and through quantitative evaluation using econometric evaluation models and techniques. Referring to this latter approach, key research questions pertain as to whether public support measures induce larger investment in $R \& D$, relative to firms' private funding (input additionality); larger innovation output, such as the introduction of technological and nontechnological innovations (output additionality); and, whether policy instruments establish changes in firms' innovative behaviour (behavioural additionality) (Antonioli and Marzucchi, 2012; Busom and Fernández-Ribas, 2008; Cerulli, 2010; Falk, 2007; Clarysse et al,, 2009; Gök and Edler, 2012; Marzucchi et al., 2015). In general, if public support measures have a positive impact on the above innovation indicators, it is interpreted as additionality effect, i.e. public 
funding is a complement to firms' private innovation activities. On the contrary, if public support measures are ineffective, public funding crowds out (substitutes) firms' innovation activities (David et al., 2000; Gök and Edler, 2012; Radicic et al., 2016). It is worth noting that the effectiveness of public support is an econometric issue, as theoretically, either effect is plausible (David et al., 2000; Dimos and Pugh, 2016).

Our study evaluates the effectiveness of R\&D support programmes on firms' technology scouting (i.e. the use of external knowledge sources), thus fitting into the category of behavioural additionality studies. Moreover, very few evaluation studies examine the effectiveness of public innovation programmes across countries. This study aims to contribute to filling this gap by examining the impact of national and international R\&D support programmes on European SMEs. In addition, our key contribution is associated with the empirical strategy employed in this study. This is among first study to explore the policy effects on technology scouting applying a copula-based endogenous switching model. Most crosssectional empirical studies employ matching estimators, although their main disadvantage is the selection on observables, i.e. unobserved firm characteristics cannot be taken into account, thus raising an issue of robustness of empirical findings to unobserved heterogeneity. Unlike matching estimators, an endogenous switching model (also known as a Roy model or tobit 5 type model, Hasebe, 2013) controls for both observed and unobserved firm characteristics.

Additionally, another contribution of our study is related to the estimated treatment parameters. Namely, most evaluation studies report the average treatment effect on the treated (ATT), without considering an issue of potential misallocation of public funding. That is, by estimating the average treatment effect (ATE), and by comparing it to the ATT, we can conclude whether public support could be more effective if randomly distributed among firms (in which case, the ATE would be larger than the ATT, as the ATE, by definition, represents the treatment effect had public support been distributed among random population of firms) (Radicic et al., 2016).

The reminder of the study is structured as follows. Section 2 provides a brief literature review of empirical studies exploring behavioural additionality. Section 3 describes the data and the empirical strategy. Section 4 discusses the empirical results, while Section 5 present main conclusions and policy implications drawn from the empirical analysis. 


\section{Literature review}

\subsection{Theoretical framework}

The traditional or neo-classical approach to public support of technology and innovation is based on the theory of market failures. Other approaches are those of evolutionary economics and systems of innovation, which focus on system failures. System failure and market failure approaches are not mutually exclusive, but rather complement each other (Smits, 2002). Market failures refer to inefficient allocation of goods and services in a market due to externalities, asymmetric information, non-competitive markets, uncertainty and risk, appropriability issues, indivisibility of knowledge generation, imperfect capital markets and missing markets for high-risk investments (Arrow, 1962). From the late 1950s onwards, the market failure rationale has provided a basis for public innovation policies (Schröter, 2009).

The evolutionary approach of system failures has been developed since the 1990s as a corollary of the development of evolutionary economics and of a resource-based, evolutionary theory of the firm (Smits, 2002). The systems of innovation approach regards innovation as an interactive, non-linear process characterized by reciprocity and feedback mechanism between economic actors in the innovation system. The central mechanism in the system is interaction (i.e. cooperation and interactive learning) between firms and other, private and public, actors (Antonioli and Marzucchi, 2012; Wanzenböck et al., 2013; Woolthuis et al., 2005). However, the systems of innovation is not the only theoretical framework that emphasizes the role of interactions on firm innovation performance. The concept of open innovation focuses on firms' use of inflows and outflows of knowledge in enhancing their innovation performance (Chesbrough, 2003, 2006). As modern firms do not innovate in isolation, they interact with their external environment by searching and exploiting external knowledge, as well as by allowing other firms to exploit the knowledge developed within the focal firm.

Among a large number of system failures, three are particularly relevant for justifying public intervention with respect to behavioural additionality. Those are strong network failures (when firms miss to identify new opportunities because of existing strong links with other actors in the system), weak network failures (arising when firms interact with other economic actors at a suboptimal level), and capability failures (when firms, in particular SMEs, lack technological and organizational capabilities to learn and consequently struggle to adapt to new technological developments) (Knockaert et al., 2014; Woolthuis et al., 2005). From the perspective of system failures, the role of innovation policy is to increase firms' knowledge 
and innovation capacity (if failures are at the firm level) or to increase institutions' capacity in addressing systems failures (if they appear at the institutional, system level) (Antonioli and Marzucchi, 2012; Gök and Edler, 2012; Wanzenböck et al., 2013). The focus in our study is on a firm-level analysis. Consequently, we explore whether innovation policy induces firms to increase their use of external knowledge sources, which in turn, will expand their knowledge and innovation capacity (Wanzenböck et al., 2013).

With respect to different types of additionality effects, input additionality and output additionality arise from the traditional or neo-classical market failure rationale, while a broader concept of behavioural additionality has emerged from the evolutionary, system failure rationale. Following Knockaert et al. (2014), behavioural additionality includes scope additionality, acceleration additionality and cognitive capacity additionality. Scope and acceleration additionalities refer to the expansion and speed up of innovation activities respectively as a result of public support. Cognitive capacity additionality encompasses network and competence additionalities, which occur when new networks and partnerships are created. These new linkages result in interorganizational learning which expands firms' competences. We hereby focus on cognitive capacity additionality. As this type of behavioural additionality is further divided into two distinct (network and competence) additionalities, we need to clarify which is the focus of our study. Knockaert et al. (2014) relate cognitive capacity additionality to the concept of external search depth and breadth (Laursen and Salter, 2006), which is termed inbound open innovation in the literature on open innovation. While the former is associated with the number of external knowledge sources, the latter emphasises the intensity of external knowledge linkages. Knockaert et al. (2014) argue that competence additionality is linked to search depth, whereas network additionality relates to search breadth. Our study focuses on individual knowledge sources and the impact of public support on the probability of their use. Therefore, our empirical findings are associated with network additionality, although the theoretical argument from the systems of innovation approach suggest that new linkages facilitate interorganizational learning which, in turn, might increases firms' competencies.

Public support can result in network additionality for several reasons. First, the literature on open innovation points out to the role of absorptive capacity (Cohen and Levinthal, 1990) in firms' interactions with the external environment. Namely, to explore external knowledge sources, firms need to possess an internal knowledge base which enables firms to explore, identify and exploit knowledge outside of their organizational boundaries. Therefore, by receiving public support, firms can expand their absorptive capacity, which, in turn, allows 
them to open up their innovation activities more extensively. A positive impact of public support on absorptive capacity is particularly relevant in the context of SMEs, given their limited financial and human resources (Radicic and Pugh, 2017). Second, public support can provide incentives for cooperation for innovation. From the perspective of system failures, the failures include the increasing costs of accessing external knowledge, lack of experience in technology scouting, and risks and uncertainties associated with the projects in which external knowledge will be exploited (Lucena and Afcha, 2014). Given that interactive learning is the prominent element of the innovation system, public support for innovation can promote knowledge exchange between actors in the system (Knockaert et al., 2014). In other words, the role of public support would be to mitigate system failures at the firm level by encouraging firms to interact with their environment and thus access external knowledge, which, in turn, would expand their learning capabilities and internal knowledge base (Antonioli and Marzucchi, 2012; Wanzenböck et al., 2013). Again, this is particularly relevant for SMEs, as they often lack managerial skills, competences and experience necessary for establishing and maintaining successful networks (Radicic et al., 2018).

\subsection{Review of empirical evidence on network additionality}

Compared to a large number of empirical studies on input additionality and to a lesser extent on output additionality (for a review see Dimos and Pugh, 2016), behavioural additionality has been the subject of only a few studies (Bellucci et al., 2019; Radicic et al., 2018). An interesting feature of the empirical analysis of behavioural additionality is that matching estimators are the only estimation methods that have been employed. The reason for this is associated with impediments imposed by the data at hand. Innovation studies, in general, mostly report empirical findings from the Community Innovation Survey (CIS) datasets. The main issues with this large-scale survey are twofold: first, the survey is not longitudinal by design, which typically precludes panel analysis; and, second, other evaluation methods, such as selection models and Instrumental Variable (IV) approaches require a valid instrument, which is hard if not impossible to find in the CIS surveys (Busom and Fernández -Ribas, 2008).

Among the first studies investigating behavioural additionality is Fier et al. (2006), who assessed the impact of public support on innovative behaviour of German firms in manufacturing sectors. Behavioural additionality is measured by three types of cooperation: with other businesses; with scientific institutions; and a combination of both. The results from 
matching estimation on the third and fourth CIS datasets are positive for all three types of cooperation. Moreover, the results indicate the heterogeneity of the impact; the largest effect of public support is on combined cooperation, and the smallest on cooperation with other businesses.

Busom and Fernández-Ribas (2008) used a subsample of Spanish manufacturing firms participating in the CIS survey in 1999 to explore the impact of national support programmes on vertical cooperation (with suppliers and customers) and with private-public partnerships (cooperation with universities or public laboratories). National programmes have a positive effect on both types of cooperation, but the effect on private-public partnership is more prominent; the policy effect on this type of partnership is twice the effect on vertical cooperation.

In the context of Spanish firms, Fernández - Ribas and Shapira (2009) investigate how local and national support programmes affect cooperation with international partners among manufacturing firms in Catalonia. The authors use the third CIS survey covering the period 1998 -2000. The estimated ATT is positive, but fairly small ( 8 percentage points). Furthermore, Afcha- Chàvez (2011) explores behavioural additionality using the Spanish ESEE survey of business strategy for the period 1998-2005. The treatment effects are estimated for vertical cooperation and private-public partnerships while separating regional from national programmes. Estimated programme effects are significantly positive only for private-public cooperation for both sources of funding, but not significant for vertical cooperation.

Antonioli et al. (2014) investigate the impact of a specific regional innovation policy (PRRITT) in the Italian region of Emilia-Romagna. The results are contrary to previous studies - the authors report no effect of public support on regional cooperation. Furthermore, regional policy shows a negative effect on horizontal cooperation. In summary, most studies report behavioural additionality, i.e. a positive impact of public support on firms' cooperation. However, the magnitude and significance vary depending on sources of funding and types of cooperative partners.

Ahn et al. (2020) examine the effectiveness of public support on cooperation in Korean manufacturing firms. Their empirical findings indicate a non-linear effect of R\&D subsidies on cooperation. That is, the impact follows an inverted U-shaped curve, which means that subsidies have a positive effect on firms' propensity to cooperate when the amount of subsidies is low, while the effect decreases for highly funded firms.

There are few studies reporting the effectiveness of innovation policy on SME innovative behaviour. Radicic et al. (2018) explore the propensity of this category of firms in traditional 
manufacturing industries to cooperate for innovation with other firms and external knowledge providers. Empirical results from seven EU regions suggest that public support does not promote cooperation with competitors, marginally promote cooperation with customers and suppliers and strongly promote cooperation with knowledge providers. Finally, Orlic et al. (2019) focus on the effectiveness of innovation policy in six Western Balkan countries. While empirical results indicate no evidence of input and output additionality in Western Balkan's SMEs, innovation policy has a positive impact on firms' innovative behaviour.

\section{Methodology}

\subsection{Model specification}

Our main hypothesis is that SMEs participating in $R \& D$ support programmes would show on average a significantly higher propensity to use specific approaches to external knowledge than non-participating firms. Our treatment variables are constructed as binary variables equal to 1 if a firm participated in national R\&D programmes, and zero otherwise (variable National participation) and equal to 1 if a firm participated in international R\&D programmes and zero otherwise (variable International participation). Regarding outcome variables, the dataset contains information on the six different approaches to acquiring external knowledge:

- Informal networking with other firms;

- Informal networking with research organizations;

- Strategic alliances with other firms;

- Non-equity alliances with other firms (a type of alliance that is not based on formal economic return for either party);

- Participation in innovation networks, S\&T parks, clusters, etc.; and

- Customer involvement (i.e. close involvement of customers in idea generation/concept development).

Each approach to acquiring external knowledge is measured on a five-point scale (from 'Don't apply at all' to 'Apply expensively'). Based on the scale, binary indicators were created for each source, where the indicator is equal to 0 if the firm reports either of three categories 
('Do not apply at all'; 'Do not apply'; or 'Neutral') and is equal to 1 if the firm reports either 'Apply' or 'Apply extensively' for a particular source of external knowledge.

Firms usually engage in formal cooperation or networking through contractual agreements to avoid the risks of knowledge leakage and partners' opportunistic behaviour. In contrast, if firms do not want to incur costs and face limitations associated with contractual agreements, they can engage in informal, noncontractual networking relations. This type of collaboration relies on mutual trust and allows firms to exchange tacit knowledge (Huang and Rice 2009; Radicic and Pugh, 2017). However, a downside to informal networking is that firms face the risks of knowledge leakage and partners' opportunistic behaviour, as they are not protected by contractual agreements (Radicic et al., 2019). Furthermore, according to Van de Vrande et al. (2009), SMEs often engage in informal networking, because this type of networking relationships does not require substantial financial resources, which are, besides limited human resources, major constraints in SME innovation activities. Our dataset contains information on two types of informal networking (with other firms and with research organization) as sources of external knowledge.

A further source of external knowledge included in the analysed survey is that of strategic alliances. Following Narula and Hagedoorn (1999), strategic alliances are formal cooperative agreements focused on long-term profit optimisation. Given their limited financial resources, SMEs are less likely to forge strategic alliances than large firms. Moreover, the resource-based view suggests that SMEs are hampered by the lack of managerial resources and competences, which can be another reason why these firms would struggle to form and maintain strategic alliances (Radicic and Pugh, 2017). However, if SMEs engage in this type of cooperation, its impact on SME performance and innovativeness is positive (Lee et al., 2010).

In addition, our dataset contains information on non-equity alliances, defined as a type of alliance that is not based on formal economic return for either party. For this reason, nonequity alliances are characterized by coopetition, whereby partners simultaneously cooperate and maintain a certain degree of competitiveness (Radicic and Pugh, 2017). According to Hagedoorn (2002), firms in high-tech and ICT sectors are more likely to forge this type of cooperative agreements, than firms in medium and low-tech industries.

Firms participate in innovation networks to benefit from knowledge exchange with other firms, public agencies and research organizations in close vicinity (similar to clusters). The aim of knowledge exchange in innovation networks is knowledge creation for economic gain (Radicic and Pugh, 2017). Like with informal types of cooperation, mutual trust is a 
necessary condition for firms to participate in innovation networks, which enables them to exchange often tacit knowledge (Pinto et al., 2015). However, geographical proximity might have a negative effect on firms' innovation activities if lock-in effects occur (Boschma, 2005).

The final source of external knowledge in our survey is customer involvement. Using customers as external knowledge source can be highly beneficial for firms' innovativeness, specifically in developing new products and technologies (Fitjar and Rodriguez-Pose, 2013), as it might improve market share and product credibility as well as reduce costs associated with introducing new products (Radicic et al., 2019). However, too much reliance on customer knowledge can be detrimental as firms might be inclined to focus on incremental changes rather than engage in more radical types of innovation (Laursen, 2011). Customer involvement in firms' innovation activities is in particular suited for SMEs, given their limited financial and human resources (Parida et al., 2012; Radicic and Pugh, 2017).

After discussing our variables of interest (i.e. technology scouting or the use of external knowledge sources), next we look at control variables that are grouped into three categories: those measuring firms' absorptive capacity; those controlling for firm characteristics; and those controlling for external, environmental (external) influences. Absorptive capacity plays a key role in firms' ability to search and absorb external knowledge (Ahn et al., 2020; Chapman et al., 2018). It is usually measured by internal R\&D activities, proxied by several measures: internal (intramural) R\&D expenditures; the share of R\&D personnel; and the presence of a separate R\&D department (Spithoven et al., 2010). Our dataset contains information on each measure, but the variable measuring $\mathrm{R} \& \mathrm{D}$ expenditures $(R \& D$ expenditure) represents total R\&D expenditures, thus including the following categories: R\&D staff salaries; contracts to outside R\&D performers; acquisition of machinery, equipment and software; purchase of patents and know-how from other organizations; training in R\&D; and, market introduction of innovations. Having a separate R\&D department is measured as a binary variable (=1 if a firm has a separate $R \& D$ department; 0 otherwise; $R \& D$ department). However, the variable measuring $\mathrm{R} \& \mathrm{D}$ expenditures ( $R \& D$ expenditure) is highly correlated with the variable measuring the share of $R \& D$ personnel (the correlation coefficient is 0.79 ), suggesting a potential problem with multicollinearity if both variables were to enter the model (Greene, 2008). Hence, the model specification includes only the former, because it is a broader measure of innovation input. We also included a binary variable $R \& D$ strategy equal to 1 if the firm has defined a R\&D and innovation strategy for the next five years (zero otherwise).

Regarding firm characteristics, we control for a firm's degree of internationalization by including a binary indicator that is equal to 1 if a firm undertakes exporting activities (Export). 
Exporting firms tend to have more incentive to innovate as a result of competitive pressure on international markets (Busom and Fernández-Ribas, 2008; Parida et al., 2012). SMEs are a heterogeneous group of firms; correspondingly, we created three binary indicators for micro firms with less than 10 employees (Micro firms), small firms having between 10 and 49 employees (Small firms) and medium-sized firms having between 50 and 249 employees (Medium firms). Moreover, the model includes two variables to control for firm-level "quasi" fixed effects (or initial conditions). The first variable (Relative capacity) is equal to 1 if firms report that their research and innovation record was leading compared to other firms in the industry five years prior to the survey (zero otherwise). The second variable (Resources for innovation) is equal to 1 if firms report having devoted fewer resources to innovation five years prior to the survey (zero otherwise).

Our model also takes into account environmental factors, such as competitive pressure, industry characteristics, and whether firms operate in technology parks and integrate technology platforms. Competitive intensity is measured as a binary indicator, equal to 1 if a firm reported that the competition is strong in its main markets (zero otherwise) (Competition). Furthermore, the model includes two binary indicators for firms located in technology parks (Tech. parks), and for those that integrate a cluster/technology platform (Tech. platform). Finally, we control for sectoral heterogeneity by constructing six industry categories following NACE classification: high tech; medium high tech; medium low tech; low tech; Information and Communication Technology (ICT); and services (as the base category).

\subsection{Data}

The dataset used in the analysis was gathered in 2010 within the MAPEER project commissioned by the European Commission's DG-Research. ${ }^{1}$ The survey questionnaire covered the period 2005-2010. The sample includes 763 SMEs from 28 European countries. The survey was targeted at the population of SMEs with less than 250 employees and an annual turnover of less than 50 million Euros (EU definition of SMEs - Article 2 of the Annex of Recommendation 2003/361/EC) (European Commission, 2005). Within the group, micro-sized firms are defined as those with less than 10 employees, small firms with 10 or more and less than 50 employees and medium-sized firms with 50 or more and less than 250 employees. The

\footnotetext{
${ }^{1}$ The description of and information about the project are given on https://cordis.europa.eu/project/rcn/93511/factsheet/en and https:/www.strast.cz/en/projects/projectslist/mapeer-sme.
} 
sample consists of 376 micro firms, 242 small firms and 145 medium-sized firms. Given the small number of firms from individual countries, we grouped them into four categories following the European Innovation Scoreboard (European Commission, 2011). The categories are as follows (for variable construction and descriptive statistics see Table A.1):

- 'Innovation leaders', countries whose innovation performance is well above the EU27 average. Our sample consists of 146 SMEs operating in countries from this category.

- 'Innovation followers', countries with performance close to the EU27 average (219 firms in our sample; this is the base or reference category);

- 'Moderate innovators', countries whose performance is below that of the EU27 average (284 firms in the sample); and

- 'Modest innovators', representing countries whose performance is well below that of the EU27 average (114 firms in the sample).

Grimpe and Sofka (2008) control for heterogeneity in national innovation systems by grouping 13 EU countries on the basis of their total national R\&D expenditure (GERD) as a share of each countries' GPD. For a robustness check, they grouped countries based on the share of firms performing $R \& D$ on a continuous basis. We opted to control for distinct national innovation systems based on both innovation inputs and outputs, and not just on innovation inputs (such as R\&D expenditure).

Table A1 in the appendix shows the variable description and summary statistics for the treatment and outcome variables, as well as for control variables. Half of the surveyed SMEs (53.2 per cent) participated in national/regional R\&D programmes in the period covered by the survey, while less than a third of firms (30.3 per cent) received public support from international sources. Regarding the use of external knowledge sources, the largest number of firms (62.5 per cent) utilizes informal networks with other firms as a source of external knowledge, followed by customer involvement (59 per cent of firms), informal networks with research organizations (52.6 per cent) and strategic alliances with other firms (44.9 per cent). The least practiced networking activity is non-equity alliances with other firms ( 24.9 per cent). With regards to firm characteristics, the modal group of SMEs' reported total R\&D expenditures as a percentage of total expenditure is the range of 11 to 20 per cent, two-thirds of firms are exporters (67.9 per cent), and a similar proportion of SMEs reports a highly competitive intensity (61.3 per cent). Moreover, 41.4 per cent of firms have a separate R\&D department, while half of the sample firms have a defined R\&D and innovation strategy for the 
period 2010-2015. Less than a third of firms are located in technology parks/areas and have integrated a technology platform (23.6 and 24.5 per cent respectively). Finally, concerning firms' innovative capacity, 44.4 per cent of firms reported to have devoted fewer resources to innovation five years prior to the survey, while 23.5 per cent of firms reported to have had a leading innovation capacity relative to their competitors.

\subsection{Empirical strategy}

Measuring the impact of a treatment includes economic agents (firms, households, and individuals), potential outcomes and treatment. We will refer to firms in our further discussion. If we denote $T_{i}$ to be treatment ( $T_{i}=1$ if a firm $i$ received a treatment and $T_{i}=0$ if not) and $Y_{i}\left(T_{i}\right)$ for outcomes of firms $i=1, \ldots, N$, where $N$ is the total population of firms, $Y_{i}(1)$ is the outcome of treated firms, $Y_{i}(0)$ is the outcome of treated firms without a treatment, and $\Delta_{i}$ is a treatment effect for a firm $i$, then

$$
\Delta_{i}=Y_{i}(1)-Y_{i}(0)
$$

Equation 1 points to the fundamental evaluation problem. To evaluate the impact of a treatment, both outcomes with and without treatment should be simultaneously observed. Therefore, the outcome for treated firms had it not been treated (counterfactual outcome - $Y_{i}(0)$ ) cannot be observed and has to be estimated, which implies that the treatment effect itself cannot be observed and must be estimated (Aakvik et al., 2005).

Further, two effects are usually estimated in the evaluation literature. The average treatment effect (ATE) indicates the difference in outcome between two counterfactuals: the outcomes for all firms if they were to be treated, $Y(1)$ (e.g. by programme participation); and the outcomes for all firms if they were not to be treated, $Y(0)$. As not all firms are treated and not all firms are untreated, both $Y(1)$ and $Y(0)$ are counterfactuals that have to be estimated.

$$
A T E=E[Y(1)-Y(0)]
$$

The average treatment effect on the treated (ATT) indicates the difference in outcomes of the treated firms with and without treatment and can be written as:

$$
A T T=E[Y(1) \mid T=1]-E[Y(0) \mid T=1]
$$


The second term $E[Y(0) \mid T=1]$ in Equation 3 is the expected outcome had treated firms not receive a treatment. This is a counterfactual outcome that is not observed. If the unconditional outcome of non-treated firms is taken to estimate the counterfactual outcome, then that would lead to selection bias, as treated and non-treated firms may differ even before a treatment assignment (Aakvik et al., 2005). The problem of selection bias can be solved by imposing certain identifying assumptions, which will be further discussed in Section 3.3. Thus, evaluation methods are designed to take into account the estimation of counterfactual outcomes as well as to control for selection bias. David et al. (2000) in their review of the evaluation innovation studies, pointed out that public support in a domain of R\&D and innovation should be treated as endogenous, given two sources of selection bias usually pertinent to the selection process: first, firms self-select themselves into public support programmes, and second, managers in public agencies adopt a 'picking the winner' strategy (see e.g. Antonelli and Crespi, 2013), that is, select those firms that are more likely to succeed in their innovation activities.

Finally, the average treatment on untreated (ATU) estimates the effect of a programme on the firms who did not receive public support and can be written as:

$$
A T U=E[Y(1) \mid T=0]-E[Y(0) \mid T=0]
$$

The first term $E[Y(1) \mid T=0]$ in Equation 4 is the expected outcome had untreated firms received a treatment. This is a counterfactual outcome that is not observed in the case of ATU. The three treatment parameters (ATT, ATU, ATE) are linked as follows:

$$
A T E=A T T * p(T=1)+A T U * p(T=0)
$$

Where $p(T=1)$ is the probability of being treated, and $p(T=0)$ is the probability of being untreated (Cerulli, 2014).

The treatment parameters are obtained by estimating a copula-based endogenous switching model. The model has two equations: Equation 6 is the outcome equation, which estimates the probability of firms using external sources of knowledge conditional on both other influences on the usage of external knowledge and the probability of participating in a support programme; and Equation 7 is the selection equation, which models the participation decision, that is, the probability that a firm will participate in a public R\&D programme. 


$$
\begin{gathered}
\text { Knowledge_source }_{i}=C_{1}+\beta \text { Participation }_{i}+\gamma Z_{i}+u_{i} \\
\text { Participation }_{i}=C_{2}+\lambda Z_{i}+\text { OObstacle }_{i}+\varepsilon_{i}
\end{gathered}
$$

Where subscript $i$ indexes each firm in the sample $1 \ldots \mathrm{n}$, where $\mathrm{n}$ is the number of firms; $C_{l}$ and $C_{2}$ represent the intercept in equations 1 and 2 respectively; the $\beta$ coefficient measures the effect of programme participation; the $\gamma$ and $\lambda$ coefficients measure the effects of control variables commonly identified in the literature (firm size, market power, exporting activities etc.) on the use of knowledge sources and the participation in R\&D programmes, respectively; the $\mathrm{k} \times 1 \theta$ vector contains coefficients that measure the participation effects of a $1 \times \mathrm{k}$ vector of indicators of firms' views on factors promoting or impeding programme participation (Obstacle), which are the anticipated identifying variables; and $u$ and $\varepsilon$ are the error terms, which capture the unobserved influences on the respective dependent variables. Full definitions and descriptive statistics for each variable are presented in Table A1 in appendix.

The independent variables must include (for econometric reasons) all the control variables from the outcome equation 6 together with at least one variable to identify equation 7. This identifying variable (Obstacle) must influence the programme participation decision but not the probability of using external knowledge sourcing. For this purpose, the survey included a question related only to programme participation whereby firms were asked about SME needs in general: "Which would you say are the specific needs for SMEs in order to participate in R\&D programmes??" In all 22 parts of this question, the corresponding indicator variable was defined as 1 if the response was "Very high importance" and 0 otherwise ("No importance", "Low importance", "Important" or "High importance"). However, only few of these variables were used as exclusion restrictions (see Table A1 for their description and summary statistics).

We constructed Equation 6 to test the hypothesis that whether or not a firm use a particular form of technology scouting depends on whether or not the firm participates in R\&D programme. This makes Participation a switching variable: if the firm participated in $R \& D$ programme (Participation $=1$ ), then it enters a state in which the use of knowledge source is hypothesised to be more likely (Regime 1); if the firm did not participate in R\&D programme 
$($ Participation $=0)$ then the firm remains in a state less conducive to using a particular knowledge source (Regime 0$)^{2}$

Because the outcome variable, Knowledge_source, can exist in one of two regimes, Equation 6 should be estimated over both regimes 1 and 0 , in which case Participation disappears as a separately estimated variable. Instead of the single Equation 6, we now have two equations, 6a and 6b, differentiated by an additional subscript: 1 for Regime 1 (for which Participation $=1$ ); and 0 for Regime 0 (for which Participation $=0$ ).

Regime 1 (Participation $=1)$

$$
\text { Knowledge_source }{ }_{i 1}=C_{11}+\gamma_{1} Z_{i 1}+u_{i 1}
$$

Regime 0 (Participation $=0)$

$$
\text { Knowledge_source }{ }_{i 0}=C_{10}+\gamma_{0} Z_{i 0}+u_{i 0}
$$

This switching process is endogenous if unobserved influences on Knowledge_source ( $u_{i 1}$ in equation $6 \mathrm{a}$ and $u_{i 0}$ in equation $6 \mathrm{~b}$ ) are correlated with unobserved influences on Participation ( $\varepsilon_{i}$ in equation 7$)$. In this three-equation model $(7,6 \mathrm{a}$ and $6 \mathrm{~b})$, a bivariate outcome (Knowledge_source) is partitioned into two regimes by a potentially endogenous bivariate switching variable (Participation). The three equations are linked by both common observed variables and, potentially, by common unobserved variables.

The estimated switching probit model can be used to generate counterfactual probabilities of acquiring external knowledge for firms in different regimes of participation (Lokshin and Glinskaya, 2009). In turn, these probabilities are used for the calculation of the average treatment effects of the treated (ATTs), the average treatment effects on the untreated (ATUs) and the average treatment effects (ATEs). As our main focus is not the interpretation of the estimated coefficients, but rather the interpretation and a comparison of the estimated treatment effects, the results of the estimated switching probit models are presented in the appendix Tables A3 and A4 for national R\&D programmes, and Tables A5 and A6 for international programmes.

\footnotetext{
${ }^{2}$ Firms responded to the questions: "Did you participate in national / regional R\&D programmes in the last 5 years? and "Did you participate in international R\&D programmes in the last 5 years?". The limitation of the corresponding Participation variable is that we lack information on the level of support. This limitation is shared with the EU's Community Innovation Survey (CIS).
} 
The original implementation of the endogenous switching model relies on the strong assumption of joint normality of the error terms (Aakvik et al., 2005). Consequently, if the normality assumption does not hold, the estimates will be inconsistent. To relax the normality assumption in sample selection models, Smith (2003) applied the copula approach, which allows different types of joint distribution in error terms between the outcome and the selection equations (Hasebe, 2013). Moreover, another advantage is that the copula method allows the model to be estimated via the maximum likelihood method, which means that the estimates are efficient (Hasebe, 2013). A copula represents a joint distribution function that binds together marginal distributions of the error terms in the selection and the outcome equations, although the copula itself is independent of marginal distributions (Smith, 2003). In our analysis, we have considered a range of copulas: Gaussian, Frank, Plackett, Clayton, AMH, FGM, Joe, and Gumbel (for detailed discussion see Smith, 2003; Trivedi and Zimmer, 2005; Hasebe, 2013). In each of the estimated models reported below, the preferred copula was determined using the Vuong test together with the AIC and BIC information criteria. The former evaluates the contribution of each copula to the log likelihood, such that the copula with the highest contribution is preferred (Hasebe, 2013). In addition, the smallest AIC or BIC suggests the preferred copula (Smith, 2003; Hasebe, 2013).

Finally, the selection equation (Equation 7) should include all independent variables from the outcome equation (Equation 6) together with at least one additional, identifying variable. Identification restrictions are imposed on the model by including variables that influence the participation decision, but do not directly affect the use of external knowledge sources. The survey questionnaire for the MAPEER project included questions related only to programme participation. Specifically, the question that served as an exclusion restriction in our model was in relation to SME needs in general: "Which would you say are the specific needs for SMEs in order to participate in R\&D programmes?”. In all 22 parts of this question, the corresponding indicator variable was defined as 1 if the response was 'Most important' and 0 otherwise ('Not important at all', 'Not important', 'Neutral' or 'Important'). For each estimated model, the selection equation included only those parts of the relevant question that were statistically significant in the selection equation and insignificant in the outcome equation.

\section{Empirical results}


The correlation matrix shown in Table A2 in the appendix indicates no issues with multicollinearity between the independent variables. For evaluating the impact of programme participation on firms' innovative behaviour, we estimated three treatment parameters - the average treatment effect on the treated (ATT), the average treatment effect on the untreated (ATU), and the average treatment effect (ATE). Estimated treatment effects for each model are presented in Table 1 (for national R\&D programmes) and in Table 2 (for international R\&D programmes). In all models, the likelihood-ratio (LR) tests reject the null hypothesis of the independence of the error terms in the outcome and the selection models (columns 3 in both tables) (Hasebe, 2013).

The estimated treatment effects shown in Table 1 are rather heterogeneous across different outcome variables. A participation in national $R \& D$ programmes increases the probability of the use of informal networking with other firms by programme participants by 6.4 percentage points (p.p.) but would have increased this probability for firms randomly selected from the entire population by 17.3 p.p. Receiving national support increases the probability of the use of informal networking with research organizations by 12.7 p.p. and would have increased the probability for firms randomly selected from the entire population by 12.7 p.p. Thus, in the case of this type of external knowledge source, there is no difference between the estimated ATT and ATE. In contrast, receiving national support increases the likelihood of using strategic and non-equity alliances as external knowledge sources by 2.3 p.p. and 14.2 p.p. respectively, while the estimated ATEs in both cases are smaller than the ATTs (and the difference is statistically significant at the $1 \%$ level). ${ }^{3}$ Likewise, concerning SMEs' participation in innovation networks, receiving national R\&D programmes increases its probability by 13.5 p.p., while a random distribution of the programmes would have increased the likelihood by 8.4 p.p. Finally, the treated firms are less likely to use customers as the knowledge sources by 6.6 p.p., while a random distribution of national R\&D support would have not resulted in a significant treatment effect. The overall pattern that can be inferred from these results on the effectiveness of national R\&D programmes is that ATT is larger than ATE when SMEs use formal knowledge sources, while the opposite holds for informal sources.

With regards to policy effects of international R\&D programmes shown in Table 2, the first interesting finding is that this source of support produces heterogenous effects on technology scouting, similar to national $\mathrm{R} \& \mathrm{D}$ programmes. More precisely, receiving international support increases the probability of using informal networking with research

\footnotetext{
${ }^{3}$ As explained in notes to Tables 1 and 2, when ATT $>$ ATE, then ATU $<$ ATT and vice versa (see equation 5).
} 
organizations (by 24 p.p.), the use of strategic alliances (by 15.4 p.p.), the use of non-equity alliances (by 21.8 p.p.), participation in innovation networks (by 16.8 p.p.) and the use of customers (by 16.4 p.p.).

The second interesting finding refers to the relationship between ATT and ATE. International R\&D programmes yield larger ATT than ATE for the use of formal scouting, while the pattern is reverse in the case of informal scouting. Accordingly, with respect to the relationship between ATT and ATE, results are consistent for both national and international R\&D programmes. 
Table 1. National support - the average treatment effect on the treated (ATT), the average treatment effect on the untreated (ATU) and the average treatment effect (ATE)

\begin{tabular}{|c|c|c|c|c|c|c|}
\hline Outcome variable & Copula & $\begin{array}{c}\text { LR test of } \\
\text { independence }\end{array}$ & $\begin{array}{c}\text { ATT } \\
(\mathrm{n}=315)\end{array}$ & $\begin{array}{c}\text { ATU } \\
(n=277)\end{array}$ & $\begin{array}{c}\text { ATE } \\
(n=592)\end{array}$ & $\begin{array}{c}\text { Relation between } \\
\text { ATT \& ATE }\end{array}$ \\
\hline $\begin{array}{l}\text { Informal networking with other } \\
\text { firms }\end{array}$ & $\mathrm{AMH}$ & $\mathrm{p}=0.000$ & $\begin{array}{c}0.064 * * * \\
(0.012)\end{array}$ & $\begin{array}{c}0.295^{* * *} \\
(0.013)\end{array}$ & $\begin{array}{c}0.173 * * * \\
(0.007)\end{array}$ & $\mathrm{ATT}<\operatorname{ATE} * * *$ \\
\hline $\begin{array}{l}\text { Informal networking with } \\
\text { research organizations }\end{array}$ & Frank & $\mathrm{p}=0.011$ & $\begin{array}{c}0.127 * * * \\
(0.009)\end{array}$ & $\begin{array}{c}0.128 * * * \\
(0.009)\end{array}$ & $\begin{array}{c}0.127 * * * \\
(0.006)\end{array}$ & $\mathrm{ATT}=\mathrm{ATE}$ \\
\hline $\begin{array}{l}\text { Strategic alliances with other } \\
\text { firms }\end{array}$ & Frank & $\mathrm{p}=0.018$ & $\begin{array}{l}0.023 * * \\
(0.011)\end{array}$ & $\begin{array}{c}-0.041 * * * \\
(0.010)\end{array}$ & $\begin{array}{l}-0.007 \\
(0.007) \\
\end{array}$ & ATT $>$ ATE $* * *$ \\
\hline $\begin{array}{l}\text { Non-equity alliances with other } \\
\text { firms }\end{array}$ & Plackett & $\mathrm{p}=0.000$ & $\begin{array}{c}0.142 * * * \\
(0.013)\end{array}$ & $\begin{array}{c}-0.127 * * * \\
(0.014)\end{array}$ & $\begin{array}{l}0.017^{* *} \\
(0.008)\end{array}$ & ATT $>$ ATE $* * *$ \\
\hline $\begin{array}{l}\text { Participation in innovation } \\
\text { networks, S\&T parks, clusters } \\
\text { etc. }\end{array}$ & Frank & $\mathrm{p}=0.000$ & $\begin{array}{c}0.135 * * * \\
(0.011)\end{array}$ & $\begin{array}{c}0.025 * * * \\
(0.012)\end{array}$ & $\begin{array}{c}0.084 * * * \\
(0.007)\end{array}$ & $\mathbf{A T T}>\mathbf{A T E} * * *$ \\
\hline $\begin{array}{l}\text { Close involvement of } \\
\text { customers in idea generation } \\
\text { and concept development }\end{array}$ & Frank & $\mathrm{p}=0.002$ & $\begin{array}{c}-0.066 * * * \\
(0.012)\end{array}$ & $\begin{array}{c}0.096^{* * *} \\
(0.012)\end{array}$ & $\begin{array}{c}0.011 \\
(0.009)\end{array}$ & $\mathrm{ATT}<\mathrm{ATE}^{* * *}$ \\
\hline
\end{tabular}

Notes: $* * * p<0.01, * * p<0.05, * p<0.10$. Bootstrapped standard errors, 1,000 replications. When ATT $>$ ATE, then ATT $>$ ATU (see formula 5) and vice versa. In the third scenario when $\mathrm{ATT}=\mathrm{ATE}$, then $\mathrm{ATT}=\mathrm{ATU}$. 
Table 2. International support - the average treatment effect on the treated (ATT), the average treatment effect on the untreated (ATU) and the average treatment effect (ATE)

\begin{tabular}{|c|c|c|c|c|c|c|}
\hline Outcome variable & Copula & $\begin{array}{c}\text { LR test of } \\
\text { independence }\end{array}$ & $\begin{array}{c}\text { ATT } \\
(n=178)\end{array}$ & $\begin{array}{c}\text { ATU } \\
(n=410)\end{array}$ & $\begin{array}{c}\text { ATE } \\
(n=588)\end{array}$ & $\begin{array}{c}\text { Relation between } \\
\text { ATT \& ATE }\end{array}$ \\
\hline $\begin{array}{l}\text { Informal networking with other } \\
\text { firms }\end{array}$ & $\mathrm{AMH}$ & $\mathrm{p}=0.000$ & $\begin{array}{c}-0.080 * * * \\
(0.016)\end{array}$ & $\begin{array}{c}0.168 * * * \\
(0.013)\end{array}$ & $\begin{array}{c}0.092 * * * \\
(0.009)\end{array}$ & $\mathrm{ATT}<\mathrm{ATE} * * *$ \\
\hline $\begin{array}{l}\text { Informal networking with } \\
\text { research organizations }\end{array}$ & Joe & $\mathrm{p}=0.001$ & $\begin{array}{c}0.240^{* * *} \\
(0.012)\end{array}$ & $\begin{array}{c}0.410 * * * \\
(0.009) \\
\end{array}$ & $\begin{array}{c}0.358^{* * *} \\
(0.008)\end{array}$ & $\mathrm{ATT}<\mathrm{ATE} * * *$ \\
\hline $\begin{array}{l}\text { Strategic alliances with other } \\
\text { firms }\end{array}$ & $\mathrm{AMH}$ & $\mathrm{p}=0.000$ & $\begin{array}{c}0.154 * * * \\
(0.016) \\
\end{array}$ & $\begin{array}{c}0.085^{* * *} \\
(0.011) \\
\end{array}$ & $\begin{array}{c}0.106^{* * *} \\
(0.009)\end{array}$ & $\mathbf{A T T}>\mathbf{A T E} * * *$ \\
\hline $\begin{array}{l}\text { Non-equity alliances with other } \\
\text { firms }\end{array}$ & Frank & $\mathrm{p}=0.000$ & $\begin{array}{c}0.218^{* * *} \\
(0.017)\end{array}$ & $\begin{array}{c}0.042 * * * \\
(0.011)\end{array}$ & $\begin{array}{c}0.096^{* * *} \\
(0.008)\end{array}$ & ATT $>$ ATE $* * *$ \\
\hline $\begin{array}{l}\text { Participation in innovation } \\
\text { networks, S\&T parks, clusters } \\
\text { etc. }\end{array}$ & $\mathrm{AMH}$ & $p=0.000$ & $\begin{array}{c}0.168 * * * \\
(0.017)\end{array}$ & $\begin{array}{c}0.073 * * * \\
(0.010)\end{array}$ & $\begin{array}{c}0.103 * * * \\
(0.008)\end{array}$ & $\mathbf{A T T}>\mathbf{A T E} * * *$ \\
\hline $\begin{array}{l}\text { Close involvement of } \\
\text { customers in idea generation } \\
\text { and concept development }\end{array}$ & Joe & $p=0.003$ & $\begin{array}{c}0.164 * * * \\
(0.019)\end{array}$ & $\begin{array}{c}0.167 * * * \\
(0.012)\end{array}$ & $\begin{array}{c}0.166^{* * *} \\
(0.010)\end{array}$ & $\mathrm{ATT}=\mathrm{ATE}$ \\
\hline
\end{tabular}

Notes: $* * * p<0.01, * * p<0.05, * p<0.10$. Bootstrapped standard errors, 1,000 replications. When ATT $>$ ATE, then ATT $>$ ATU (see formula 5) and vice versa. In the third scenario when $\mathrm{ATT}=\mathrm{ATE}$, then $\mathrm{ATT}=\mathrm{ATU}$. 


\section{Conclusions and policy implications}

This study reports the impact of national and international R\&D programmes on behavioural additionality in European SMEs, in particular, focusing on technology scouting. While receiving national $R \& D$ programmes increases the likelihood of using strategic and nonequity alliances as the knowledge source, receiving international R\&D programmes also stimulates informal networking with research organizations and the use of customers.

Besides reporting the policy effects on treated firms, our analysis also provides the estimates of policy effects had R\&D programmes been randomly allocated. Analysing each source of external knowledge separately, the results suggest that a random distribution of national $R \& D$ support measures would increase the probability of using informal networking with other and customer involvement to a larger degree than the distribution using current selection criteria. In the case of using informal networking with research organisations, random allocation would yield the same effect as the current selection process. This pattern is reinforced in the case of a random allocation of international R\&D programmes, that is, random allocation of international R\&D programmes would increase the likelihood of using informal networking (with both other firms and research organisations), whereas the current selection process would be more beneficial when firms use formal sources of knowledge. Customer involvement would benefit to the same extent whether support is randomly allocated or not.

Therefore, the overall results seem to indicate that, for the use of informal sources of external knowledge, a random distribution of R\&D measures would have a substantially larger effect even if only by reducing crowding out - rather than using current selection criteria. The opposite is found for the use of formal, strategic knowledge sources. That is, random allocation would not yield a larger policy effect compared to a conventional selection process.

This study makes two contributions to the literature. First, it explores behavioural additionality applying the empirical strategy that takes into account both observed and unobserved heterogeneity. Our results suggest that public support measure might not have an additionality effect among surveyed firms. Namely, national public support measures crowd out SMEs' use of customers as a source of external knowledge, while international support crowds out the use of informal networking with other firms.

Second, the study reports the ATEs and compares it to the ATTs to identify potential misallocation of public funding, and thus suggesting potential improvements with that respect. By randomly allocating public funding, public agencies could increase the effectiveness of 
public support measures on firms' acquisition of informal external knowledge. Current selection criteria should remain in place for the purpose of fostering formal use of knowledge sources. Therefore, for informal technology scouting, a larger behavioural additionality among European SMEs might be achieved with a lottery system of public funding distribution (Radicic et al., 2016). These results could be explained by looking at the differences between formal and informal technology scouting. The former entails large costs and contractual obligations, while the latter is based on mutual trust and is a less costly form of scouting. Consequently, current selection criteria are effective in supporting firms that engage in formal technology scouting, whereas random allocation would benefit SMEs when they use informal knowledge sources.

Another important issue should be mentioned. Although we did not separately analyse developed and developing/emerging economies, our policy recommendation concerning random allocation could be particularly relevant for less developed economies. Specifically, a selection process in less developed countries is more likely to be hampered by information asymmetry and bureaucratic incompetence (Wang et al., 2017). In the case of a random allocation of public funds, these potentially limiting factors would have no effect on the distribution of public funds, as the selection process would be randomized.

The practical implementation of random allocation is divided into three stages: application, screening, and lottery. The first stage includes firms submitting their application form. Applicants are screened for eligibility or "due diligence" checking, which ensures that participating firms meet eligibility requirements - e.g. with respect to proposed activities and solvency. Finally, eligible proposals are randomly selected for support.

Consistent with these proposals, the case for random allocation is gaining influence amongst policy makers trough randomised controlled trials (RTC) projects. For instance, the SME innovation voucher programme in the Netherlands was implemented such that vouchers were allocated by lottery. Cornet et al. (2006) evaluated the effectiveness of this programme and found that firms used eight (out of 10) vouchers for their innovation activities, which would not have been happen without public support. This is a rather large additional effect given that evaluation studies usually report positive, but small policy effects (Dimos and Pugh, 2016; Radicic et al, 2016). Furthermore, since 2010, five publicly funded randomised controlled trials (RCT) projects have been undertaken in the UK designed to explore the effectiveness of public support on innovation in small firms (for more details about each project, see Roper, 2018). As an illustration, the first RCT project is called "Creative Credits", which is a voucher programme with random allocation to support SME purchases of creative services. A short-run evaluation 
of the programme has shown a positive and large policy effect of the use of creative services on SME innovation activities (Bakhshi et al., 2011).

Although our study provides new insights into behavioural additionality, future research might explore how public support measures affect firms' innovative behaviour in medium and long run, which would require the availability of longitudinal data (Ahn et al., 2020; Radicic et al., 2019). Furthermore, other types of behavioural additionality (such as cognitive capacity additionality, see e.g. Knockaert et al., 2014) could be explored. Finally, gathering and analysing information on the selection process could be a fruitful avenue for further exploration of the effectiveness of public funding (Antonelli and Crespi, 2013).

\section{References}

Aakvik, A., Heckman, J. and Vytlacil, E. (2005), "Estimating treatment effects for discrete outcomes when responses to treatment vary: an application to Norwegian vocational rehabilitation programs", Journal of Econometrics, Vol. 125 No. (1-2), pp. 15-51.

Afcha Chàvez, S.M. (2011), "Behavioural additionality in the context of regional innovation policy in Spain”, Innovation: Management, Policy \& Practice, Vol. 13 No.1, pp. 95110.

Ahn, J.M., Lee, W. and Mortara, L. (2020), "Do government R\&D subsidies stimulate collaboration initiatives in private firms?" Technological Forecasting \& Social Change, Vol. 151, 119840.

Antonelli, C. and Crespi, F. (2013), "The "Matthew effect" in R\&D public subsidies: The Italian evidence", Technological Forecasting and Social Change, Vol. 80 No. 8, pp. $1523-1534$.

Antonioli, D. and Marzucchi, A. (2012), "Evaluating the additionality of innovation policy. A review focused on the behavioural dimension", World Review of Science, Technology and Sustainable Development, Vol. 9 No. 2-4, pp. 124-148.

Antonioli, D., Marzucchi, A. and Montresor, S. (2014), "Regional Innovation Policy and Innovative Behaviour: Looking for Additional Effects", European Planning Studies, Vol. 22 No. 1, pp. 64-83.

Arrow, K.J. (1962), "Economic welfare and the allocation of resources for invention", in Nelson, R.R. (Eds), The Rate and Direction of Inventive Activity: Economic and Social Factors, pp. 609-625, Princeton University Press for N.B.E.R., Princeton.

Bakhshi H., Edwards J., Roper S., Scully, J. and Shaw, D. (2011), "Creating innovation in small and medium-sized enterprises: Evaluating the short-term effects of the Creative Credits pilot", NESTA Working Paper May 2011.

Barney, J. (1991), "Firm Resources and Sustained Competitive Advantage", Journal of Management, Vol. 17 No. 1, pp. 99-120.

Bellucci, A., Pennacchio, L. and Zazzaro, A. (2019), "Do government R\&D subsidies stimulate collaboration initiatives in private firms", Small Business Economics, Vol. 52, pp. 213240.

Boschma, R. (2005), "Proximity and Innovation: A Critical Assessment”, Regional Studies, Vol. 39 No. 1, pp. 61-74.

Busom, I. (2000), “An Empirical Evaluation of the Effects of R\&D Subsidies”, Economics of Innovation and New Technology, Vol. 9 No. 2, pp. 111-148.

Busom, I., and Fernández-Ribas, A. (2008), "The impact of firm participation in R\&D 
programmes on R\&D partnerships", Research Policy, Vol. 37 No. 2, pp. 240-257.

Cerulli, G. (2010), "Modelling and Measuring the Effect of Public Subsidies on Business R\&D: A Critical Review of the Econometric Literature", Economic Record, Vol. 86 No. 274, pp. 421-449.

Cerulli, G. (2014), "ivtreatreg: A command for fitting binary treatment models with heterogeneous response to treatment and unobservable selection", Stata Journal, Vol. 14 No. 3, pp. 423-480.

Chapman, G., Lucena, A. and Afcha, S. (2018), "R\&D subsidies \& external collaborative breadth: Differential gains and the role of collaboration experience", Research Policy, Vol. 47, pp. 623-636.

Chesbrough, H. (2003), "Open Innovation. The New Imperative for Creating and Profiting from Technology", Harvard Business School Press, Boston, MA.

Chesbrough, H. (2006), "Open innovation: a new paradigm for understanding industrial innovation", in Chesbrough, H., Vanhaverbeke, W. and West, J. (Eds.), Open Innovation. Researching a New Paradigm, pp. 1-14, Oxford University Press, Oxford.

Clarysse, B., Wright, M. and Mustar, P. (2009), "Behavioural additionality of R\&D subsidies: A learning perspective", Research Policy, Vol. 38 No. 10, pp. 1517-1533.

Club des Organismes de Recerche Associes (CLORA) (2013), www.clora.eu

Cohen, W. and Levinthal, D. (1990), “Absorptive Capacity: A New Perspective on Learning and Innovation", Administrative Science Quarterly, Vol. 35 No. 1, pp. 128-152.

Cornet M., Vroomen B. and van der Steeg, M. (2006), "Do innovation vouchers help SMEs to cross the bridge towards science?" Discussion Paper 58, CPB Netherlands Bureau for Economic Policy Analysis.

David, P.A., Hall, B.H. and Toole, A.A. (2000), "Is Public R\&D a Complement or Substitute for Private R\&D? A review of the Econometric Evidence", Research Policy, Vol. 29 No. 4-5, pp. 497-529.

Dimos, C., and Pugh, G. (2016), "The effectiveness of R\&D subsidies: A meta-regression analysis of the evaluation literature", Research Policy, Vol. 45 No. 4, pp. 797-815.

Edler, J., Berger, M., Dinges, M. and Gök, A. (2012), “The practice of evaluation in innovation policy in Europe", Research Evaluation, Vol. 21 No. 3, pp. 167-182.

Emden, Z., Calantone, R.J., and Droge, C. (2006), "Collaborating for New Product Development: Selecting the Partner with Maximum Potential to Create Value", Journal of Product Innovation Management, Vol. 23 No. 4, pp. 330-341.

European Commission (2005), SME definition, available at: http://ec.europa.eu/enterprise/policies/sme/facts-figures-analysis/smedefinition/index en.htm

European Commission (2010), European Innovation Scoreboard, Brussels.

European Commission (2011), European Innovation Scoreboard, Brussels.

European Commission (2013a), European Innovation Scoreboard, Brussels.

European Commission (2013b), A recovery on the horizon, Annual Report on European SMEs 2012/2013.

Falk, R. (2007), "Measuring the effects of public support schemes on firms' innovation activities: Survey evidence from Austria", Research Policy, Vol. 36 No. 5, pp. 665679.

Fernández-Ribas, A. and Shapira, P. (2009), “The role of national and regional-level innovation programs in stimulating international cooperation in innovation", International Journal of Technology Management, Vol. 48 No. 4, pp. 473-498.

Fier, A., Aschhoff, B. and Löhlein, H. (2006), "Behavioural Additionality of Public R\&D 
Funding in Germany", in OECD (Eds), Government R\&D Funding and Company Behaviour: Measuring Behavioural Additionality, pp. 127-149, OECD Publishing, Paris.

Fitjar, R.D. and Rodriguez-Pose, A. (2013), "Firm collaboration and modes of innovation in Norway", Research Policy, Vol. 42 No. 1, pp. 128-138.

Gök, A. and Edler, J. (2012), "The use of behavioural additionality evaluation in innovation policy making”, Research Evaluation, Vol. 21 No. 4, pp. 306-318.

Grimpe, C. and Sofka, W. (2008), "Search patterns and absorptive capacity: Low- and hightechnology sectors in European countries", Research Policy, Vol. 38 No. 3, pp. 495 506.

Greene, W.H. (2008), Econometric analysis, 6th ed., Prentice Hall, Boston, MA.

Hagedoorn, J. (2002), "Inter-firm R\&D partnerships: an overview of major trends and patterns since 1960", Research Policy, Vol. 31 No. 4, pp. 477-492.

Hasebe, T. (2013), "Copula-based maximum-likelihood estimation of sample selection models", Stata Journal, Vol. 13 No. 3, pp. 547-573.

Hauknes, J. and Nordgren, L. (1999), "Economic rationales of government involvement in innovation and the supply of innovation-related service", STEP Working Paper 8/99.

Huang, F. and J. Rice (2009), "The Role of Absorptive Capacity in Facilitating 'Open Innovation' Outcomes: A Study of Australian SMEs in the Manufacturing Sector", International Journal of Innovation Management, Vol. 13 No. 2, pp. 201-220.

Huizingh, E.K.R.E. (2011), "Open innovation: State of the art and future perspectives", Technovation, Vol. 31 No. 1, pp. 2-9.

Knockaert, M., Spithoven, A. and Clarysse, B. (2014), "The impact of technology intermediaries on firm cognitive capacity additionality”, Technological Forecasting \& Social Change, Vol. 81 No. 1, pp. 376-387.

Laursen, K. (2011), "User-producer interaction as a driver of innovation: Costs and advantages in an open innovation model”, Science and Public Policy, Vol. 38 No. 9, pp. 713723.

Lee, S., Park, G., Yoon, B. and Park, J. (2010), "Open innovation in SMEs - An intermediated network model”, Research Policy, Vol. 39 No. 2, pp. 290-300.

Lokshin, M. and Glinskaya, E. (2009), "The Effect of Male Migration on Employment Patterns of Women in Nepal", World Bank Economic Review, Vol. 23, No. 3, pp. 481-507.

Lucena, A. and Afcha, S. (2014), "Public support for R\&D, knowledge sourcing and firm innovation: Examining a mediated model with evidence from the manufacturing industries", CENTRUM Católica Working Paper No. 2014-06-0002, Pontificia Universidad Católica del Perú.

Marzucchi, A., Antonioli, D. and Montresor, S. (2015), "Industry-research co-operation within and across regional boundaries. What does innovation policy add?" Papers in Regional Science, Vol. 94 No. 3, pp. 499-524.

Narula, R. (2004), "R\&D collaboration by SMEs: new opportunities and limitations in the face of globalization", Technovation, Vol. 24 No. 2, pp. 153-161.

Narula, R. and Hagedoorn, J. (1999), "Innovating thorough strategic alliances: moving towards international partnerships and contractual agreements", Technovation, Vol. 19 No. 5, pp. 283-294.

Orlic, E., Radicic, D. and Balavac, M. (2019), "R\&D and innovation policy in the Western Balkans: are there additionality effects?" Science and Public Policy, https://doi.org/10.1093/scipol/scz036 
Parida, V., Westerberg, M. and Frishammar, J. (2012), "Inbound Open Innovation Activities in High Tech SMEs: The Impact on Innovation Performance", Journal of Small Business Management, Vol. 50 No. 2, pp. 283-309.

Peteraf, M.A. (1993), "The cornerstones of competitive advantage: A resource- based view", Strategic Management Journal, Vol. 14 No. 3, pp. 179-191.

Pinto, H., M. T. de Noronha, and C. Faustino (2015), "Knowledge and Cooperation Determinants of Innovation Networks: A Mixed Methods Approach to the Case of Portugal", Journal of Technology Management \& Innovation, Vol. 10 No.1, pp. 83102.

Radicic, D., Douglas, D., Pugh, G. and Jackson, I. (2019), “Cooperation for innovation and its impact on technological and non-technological innovations: empirical evidence for European SMEs in traditional manufacturing industries", International Journal of Innovation Management, Vol. 23 No. 5, 1950046.

Radicic, D. and Pugh, G. (2017), "Performance effects of open innovation in European small and medium-sized enterprises", Journal of Small Business Management, Vol 55 No. S1, pp. 76-114.

Radicic, D., Pugh, G., Hollanders, H., Wintjes, R. and Fairburn, J. (2016), “The impact of innovation support programmes on SME innovation in traditional manufacturing industries: an evaluation for seven EU regions," Environment and Planning C: Government and Policy, Vol. 34 No. 8, pp. 1425-1452.

Radicic, D., Pugh, G., and Douglas, D. (2018), "Promoting cooperation in innovation ecosystems: evidence from European traditional manufacturing SMEs", Small Business Economics. https://doi.org/10.1007/s11187-018-0088-3

Roper, S. (2018), "Using RCTs as a research method for SME policy research: The UK experience", Enterprise Research Centre (ERC) Research Paper 66.

Schröter, A. (2009), "New Rationales for Innovation Policy? A Comparison of the Systems of Innovation Policy Approach and the Neoclassical Perspective", Jena Max Planck Institute of Economics Economic Research Paper 2009-033.

Smits, R. (2002), "Innovation studies in the 21st century: Questions from a user's perspective", Technological Forecasting and Social Change, Vol. 69 No. 9, pp. 861-883.

Spithoven, A., Frantzen, D. and Clarysse, B. (2010), "Heterogeneous Firm-Level Effects of Knowledge Exchanges on Product Innovation: Differences between Dynamic and Lagging Product Innovators", Journal of Product Innovation Management, Vol. 27 No. 3, pp. 362-381.

Van de Vrande, V., de Jong, J.P.J., Vanhaverbeke, W. and de Rochemont, M. (2009), “Open innovation in SMEs: Trends, motives and management challenges", Technovation, Vol. 29 No. 6-7, pp. 423-437.

Wang, Y., Li., J. and Furman, J.L. (2017), "Firm performance and state innovation funding: Evidence from China's Innofund program”, Research Policy, Vol. 46, pp. 1142-1161.

Wanzenboeck, I., Scherngell, T. and Fischer, M.M. (2013), "How do firm characteristics affect behavioural additionalities of public R\&D subsidies? Evidence for the Austrian transport sector", Technovation, Vol. 33 No. 2-3, pp. 66-77.

Woolthuis, R.K., Lankhuizen, M., and Gilsing, V. (2005), “A system failure framework for innovation policy design", Technovation, Vol. 25, pp. 609-619. 


\section{Appendix}

Table A1. Variable definition and descriptive statistics

\begin{tabular}{|c|c|c|}
\hline Variables & Variable construction & $\begin{array}{c}\text { Mean } \\
\text { (standard } \\
\text { deviation) }\end{array}$ \\
\hline Treatment variables & & \\
\hline National participation & $\begin{array}{l}\mathrm{DV}=1 \text { if a firm participated in national/regional } \mathrm{R} \& \mathrm{D} \text { programmes in the last five } \\
\text { years; zero otherwise }\end{array}$ & $\begin{array}{c}0.532 \\
(0.499) \\
\end{array}$ \\
\hline International participation & $\begin{array}{l}\mathrm{DV}=1 \text { if a firm participated in international } \mathrm{R} \& \mathrm{D} \text { programmes in the last five years; } \\
\text { zero otherwise }\end{array}$ & $\begin{array}{c}0.303 \\
(0.460)\end{array}$ \\
\hline Outcome variables - use of external knowledge & +2 & \\
\hline Informal networking with other firms & $\begin{array}{l}\mathrm{DV}=1 \text { if the response was 'Apply' or 'Apply extensively'; =0 if 'Don't apply at all', } \\
\text { 'Don't apply' or 'Neutral' to the question "Do you have a specific approach towards } \\
\text { acquiring external knowledge - Informal networking with other firms" }\end{array}$ & $\begin{array}{c}0.625 \\
(0.485)\end{array}$ \\
\hline Informal networking with research organizations & $\begin{array}{l}\mathrm{DV}=1 \text { if the response was 'Apply' or 'Apply extensively'; =0 if 'Don't apply at all', } \\
\text { 'Don't apply' or 'Neutral' to the question "Do you have a specific approach towards } \\
\text { acquiring external knowledge - Informal networking with research organizations" }\end{array}$ & $\begin{array}{c}0.526 \\
(0.500)\end{array}$ \\
\hline Strategic alliances with other firms & $\begin{array}{l}\mathrm{DV}=1 \text { if the response was 'Apply' or 'Apply extensively'; =0 if 'Don't apply at all', } \\
\text { 'Don't apply' or 'Neutral' to the question "Do you have a specific approach towards } \\
\text { acquiring external knowledge - Strategic alliances with other firms" }\end{array}$ & $\begin{array}{c}0.449 \\
(0.498)\end{array}$ \\
\hline Non-equity alliances with other firms & $\begin{array}{l}\mathrm{DV}=1 \text { if the response was 'Apply' or 'Apply extensively'; =0 if 'Don't apply at all', } \\
\text { 'Don't apply' or 'Neutral' to the question "Do you have a specific approach towards } \\
\text { acquiring external knowledge - Non-equity alliances with other firms" }\end{array}$ & $\begin{array}{c}0.249 \\
(0.433)\end{array}$ \\
\hline $\begin{array}{l}\text { Participation in innovation networks, S\&T parks, } \\
\text { clusters etc. }\end{array}$ & $\begin{array}{l}\mathrm{DV}=1 \text { if the response was 'Apply' or 'Apply extensively'; =0 if 'Don't apply at all', } \\
\text { 'Don't apply' or 'Neutral' to the question "Do you have a specific approach towards } \\
\text { acquiring external knowledge - Participation in innovation networks, S\&T parks, } \\
\text { clusters etc." }\end{array}$ & $\begin{array}{c}0.408 \\
(0.492)\end{array}$ \\
\hline $\begin{array}{l}\text { Close involvement of customers in idea generation } \\
\text { and concept development }\end{array}$ & $\begin{array}{l}\mathrm{DV}=1 \text { if the response was 'Apply' or 'Apply extensively'; }=0 \text { if 'Don't apply at all', } \\
\text { 'Don't apply' or 'Neutral' to the question "Do you have a specific approach towards } \\
\text { acquiring external knowledge - Close involvement of end users/customers in idea } \\
\text { generation/concept development" }\end{array}$ & $\begin{array}{c}0.590 \\
(0.492)\end{array}$ \\
\hline Control variables & & - \\
\hline R\&D expenditure & $\begin{array}{l}\text { Annual R\&D expenditures as } \% \text { of total expenditure (including both intramural and } \\
\text { extramural R\&D activities; purchase of patents and know-how; training in R\&D; } \\
\text { and market introduction of innovation) }=1 \text { if the share is } 0-10 \% ;=2 \text { if the share is } \\
11-20 \% ;=3 \text { if the share is } 21-50 \% ;=4 \text { if the share is }>50 \%\end{array}$ & $\begin{array}{c}2.064 \\
(1.132)\end{array}$ \\
\hline Export & Geographic markets where firms sell goods or services, $D V=1$ if a firm engages in & 0.679 \\
\hline
\end{tabular}




\begin{tabular}{|c|c|c|}
\hline 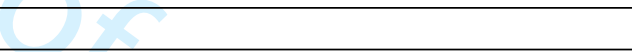 & exporting activities; zero otherwise & $(0.467)$ \\
\hline Competition & $\begin{array}{l}\text { DV }=1 \text { if a firm responded 'Very strong' to the question "How would you judge } \\
\text { the competition in your main market(s)"; otherwise } 0\end{array}$ & $\begin{array}{c}0.613 \\
(0.487) \\
\end{array}$ \\
\hline $\mathrm{R} \& \mathrm{D}$ department & $\mathrm{DV}=1$ if a firm has a separate $\mathrm{R} \& \mathrm{D}$ department; zero otherwise & $\begin{array}{c}0.414 \\
(0.493)\end{array}$ \\
\hline R\&D strategy & $\begin{array}{l}\mathrm{DV}=1 \text { if a firm has developed R\&D and innovation strategy for the next five years; } \\
\text { zero otherwise }\end{array}$ & $\begin{array}{c}0.505 \\
(0.500) \\
\end{array}$ \\
\hline Resources for innovation & $\begin{array}{l}\text { DV = } 1 \text { if the response was 'Fewer' to the question "Resources devoted by the firm } \\
\text { to innovation compared to the present"; = } 0 \text { if 'About the same' or 'More' }\end{array}$ & $\begin{array}{c}0.444 \\
(0.497) \\
\end{array}$ \\
\hline Relative capacity & $\begin{array}{l}\text { DV }=1 \text { the response was 'Leading' to the question "The firm's research and } \\
\text { innovation record relative to other firms in their industry in } 2005 \text { "; = } 0 \text { if 'Average' } \\
\text { and 'Lagging' }\end{array}$ & $\begin{array}{c}0.235 \\
(0.424)\end{array}$ \\
\hline Tech. park & $\mathrm{DV}=1$ if a firm is located in a technology park/area; zero otherwise & $\begin{array}{r}0.236 \\
(0.425) \\
\end{array}$ \\
\hline Tech. platform & $\mathrm{DV}=1$ if a firm integrates a technology platform; zero otherwise & $\begin{array}{c}0.245 \\
(0.430)\end{array}$ \\
\hline Transparent proposal evaluation procedures & $\begin{array}{l}\text { DV }=1 \text { if a firm responded 'Most important' to the question "Which would you say } \\
\text { are the specific needs for SMEs in order to participate in R\&D programmes? - } \\
\text { Transparent proposal evaluation procedures; zero otherwise }\end{array}$ & $\begin{array}{c}0.432 \\
(0.496)\end{array}$ \\
\hline Simple reporting requirements & $\begin{array}{l}D V=1 \text { if a firm responded 'Most important' to the question "Which would you say } \\
\text { are the specific needs for SMEs in order to participate in R\&D programmes? - } \\
\text { Simple reporting requirements; zero otherwise }\end{array}$ & $\begin{array}{c}0.448 \\
(0.498)\end{array}$ \\
\hline Adequate networks of potential partners & $\begin{array}{l}D V=1 \text { if a firm responded 'Most important' to the question "Which would you say } \\
\text { are the specific needs for SMEs in order to participate in R\&D programmes? - } \\
\text { Adequate networks of potential partners; zero otherwise }\end{array}$ & $\begin{array}{c}0.260 \\
(0.439)\end{array}$ \\
\hline Adequate marketing of programmes & $\begin{array}{l}\mathrm{DV}=1 \text { if a firm responded 'Most important' to the question "Which would you say } \\
\text { are the specific needs for SMEs in order to participate in R\&D programmes? - } \\
\text { Adequate marketing of programmes; zero otherwise }\end{array}$ & $\begin{array}{c}0.240 \\
(0.427)\end{array}$ \\
\hline Micro firms & $\mathrm{DV}=1$ if a firm has less than 10 employees; zero otherwise & $\begin{array}{c}0.478 \\
(0.500) \\
\end{array}$ \\
\hline Small firms & $\mathrm{DV}=1$ if a firm has more than then 10 but less than 50 employees; zero otherwise & $\begin{array}{c}0.333 \\
(0.472) \\
\end{array}$ \\
\hline Medium-sized firms & $\begin{array}{l}\mathrm{DV}=1 \text { if a firm has more than then } 50 \text { but less than } 250 \text { employees; zero } \\
\text { otherwise }\end{array}$ & $\begin{array}{r}0.189 \\
(0.392) \\
\end{array}$ \\
\hline Innovation leaders & $\mathrm{DV}=1$ if countries are Denmark, Finland, Germany and Sweden; zero otherwise & $\begin{array}{c}0.172 \\
(0.378)\end{array}$ \\
\hline Innovation followers & $\begin{array}{l}\mathrm{DV}=1 \text { if countries are Austria, Belgium, Cyprus, Estonia, France, Ireland, } \\
\text { Luxembourg, Netherlands, Slovenia and the United Kingdom; zero otherwise (base } \\
\text { category) }\end{array}$ & $\begin{array}{c}0.298 \\
(0.457)\end{array}$ \\
\hline
\end{tabular}




\begin{tabular}{|c|c|c|}
\hline Moderate innovators & $\begin{array}{l}\mathrm{DV}=1 \text { if countries are Czech Republic, Greece, Hungary, Italy, Malta, Poland, } \\
\text { Portugal, Slovakia and Spain; zero otherwise }\end{array}$ & $\begin{array}{r}0.407 \\
(0.492)\end{array}$ \\
\hline Modest innovators & $\begin{array}{l}\mathrm{DV}=1 \text { if countries are Bulgaria, Latvia, Lithuania, Romania and Bosnia and } \\
\text { Herzegovina; zero otherwise }\end{array}$ & $\begin{array}{r}0.123 \\
(0.329) \\
\end{array}$ \\
\hline High-technology industries & $\begin{array}{l}\mathrm{DV}=1 \text { if firms operate in high-technology intensive industries; zero otherwise } \\
\text { (NACE classification rev 1.1) }\end{array}$ & $\begin{array}{r}0.198 \\
(0.399)\end{array}$ \\
\hline Medium high-technology industries & $\begin{array}{l}\mathrm{DV}=1 \text { if firms operate in medium high-technology intensive industries; zero } \\
\text { otherwise }\end{array}$ & $\begin{array}{r}0.130 \\
(0.337) \\
\end{array}$ \\
\hline Medium low-technology industries & $\begin{array}{l}\mathrm{DV}=1 \text { if firms operate in medium low-technology intensive industries; zero } \\
\text { otherwise }\end{array}$ & $\begin{array}{r}0.128 \\
(0.335)\end{array}$ \\
\hline Low-technology industries & $\mathrm{DV}=1$ if firms operate in low-technology intensive industries; zero otherwise & $\begin{array}{r}0.142 \\
(0.349)\end{array}$ \\
\hline $\begin{array}{l}\text { Information and Communication Technology (ICT) } \\
\text { industries }\end{array}$ & $\mathrm{DV}=1$ if firms operate in ICT industries; zero otherwise & $\begin{array}{r}0.211 \\
(0.408) \\
\end{array}$ \\
\hline Service sectors & $\mathrm{DV}=1$ if firms operate in service industries; zero otherwise (base category) & $\begin{array}{r}0.191 \\
(0.393\end{array}$ \\
\hline
\end{tabular}




\section{Table A.2. The correlation matrix}

\begin{tabular}{|c|c|c|c|c|c|c|c|c|}
\hline $\begin{array}{c}\text { Independent } \\
\text { variables }\end{array}$ & $\begin{array}{c}\text { R\&D } \\
\text { expenditure }\end{array}$ & Export & Competition & $\begin{array}{l}\text { Relative } \\
\text { capacity }\end{array}$ & $\begin{array}{l}\text { Resources } \\
\text { for } \\
\text { innovation }\end{array}$ & $\begin{array}{c}\text { R\& D } \\
\text { strategy }\end{array}$ & $\begin{array}{c}\text { R\&D } \\
\text { department }\end{array}$ & $\begin{array}{l}\text { Tech. } \\
\text { park }\end{array}$ \\
\hline \multicolumn{9}{|l|}{$\begin{array}{l}\text { R\&D } \\
\text { expenditure }\end{array}$} \\
\hline Export & $0.164^{* * *}$ & 1 & & & & & & \\
\hline Competition & $-0.108^{* *}$ & 0.004 & 1 & & & & & \\
\hline $\begin{array}{l}\text { Relative } \\
\text { capacity }\end{array}$ & $0.282^{* * *}$ & $0.116^{* * *}$ & $-0.092^{* *}$ & 1 & & & & \\
\hline $\begin{array}{l}\text { Resources } \\
\text { for } \\
\text { innovation }\end{array}$ & 0.030 & -0.019 & $0.145^{* * *}$ & $-0.102^{* *}$ & 1 & & & \\
\hline $\begin{array}{l}\text { R\&D } \\
\text { strategy }\end{array}$ & $0.328^{* * *}$ & $0.144^{* * *}$ & -0.037 & $0.142^{* * *}$ & $0.124^{* * *}$ & 1 & & \\
\hline $\begin{array}{l}\mathrm{R} \& \mathrm{D} \\
\text { department }\end{array}$ & $0.322^{* * *}$ & $0.203^{* * *}$ & 0.019 & $0.093^{* *}$ & $0.112^{* * *}$ & $0.358^{* * *}$ & 1 & \\
\hline Tech, park & $0.320^{* * *}$ & $0.093^{* *}$ & $-0.121^{* * *}$ & $0.142^{* * *}$ & -0.002 & $0.122^{* * *}$ & $0.097^{* *}$ & 1 \\
\hline $\begin{array}{l}\text { Tech. } \\
\text { platform }\end{array}$ & $0.193^{* * *}$ & $0.072 *$ & 0.065 & 0.018 & $0.202^{* * *}$ & $0.179^{* * *}$ & $0.143^{* * *}$ & $0.228^{* * *}$ \\
\hline
\end{tabular}


Table A3. Results from the copula approach for national R\&D programmes - part 1

\begin{tabular}{|c|c|c|c|c|c|c|c|c|c|}
\hline Independent variables & $\begin{array}{l}\text { Selection } \\
\text { equation }\end{array}$ & $\begin{array}{l}\text { Outcome } \\
\text { equation } \\
\text { regime } 0\end{array}$ & $\begin{array}{l}\text { Outcome } \\
\text { equation } \\
\text { regime } 1\end{array}$ & $\begin{array}{l}\text { Selection } \\
\text { equation }\end{array}$ & $\begin{array}{l}\text { Outcome } \\
\text { equation } \\
\text { regime } 0\end{array}$ & $\begin{array}{l}\text { Outcome } \\
\text { equation } \\
\text { regime } 1\end{array}$ & $\begin{array}{l}\text { Selection } \\
\text { equation }\end{array}$ & $\begin{array}{l}\text { Outcome } \\
\text { equation } \\
\text { regime } 0\end{array}$ & $\begin{array}{l}\text { Outcome } \\
\text { equation } \\
\text { regime } 1\end{array}$ \\
\hline \multirow[t]{2}{*}{ R\&D expenditure } & $0.191 * * *$ & 0.021 & -0.002 & $0.195 * * *$ & $0.059 *$ & 0.014 & $0.194 * * *$ & $0.065^{*}$ & 0.024 \\
\hline & $(0.065)$ & $(0.036)$ & $(0.027)$ & $(0.066)$ & $(0.032)$ & $(0.027)$ & $(0.066)$ & $(0.034)$ & $(0.029)$ \\
\hline \multirow[t]{2}{*}{ Export } & 0.174 & $0.116^{*}$ & 0.076 & 0.182 & $0.124 * *$ & 0.022 & 0.185 & 0.047 & 0.024 \\
\hline & $(0.128)$ & $(0.065)$ & $(0.065)$ & $(0.129)$ & $(0.057)$ & $(0.065)$ & $(0.129)$ & $(0.060)$ & $(0.065)$ \\
\hline \multirow[t]{2}{*}{ Competition } & $-0.275 * *$ & -0.052 & 0.024 & $-0.260 * *$ & -0.079 & 0.044 & $-0.251 * *$ & $-0.113 *$ & 0.009 \\
\hline & $(0.119)$ & $(0.062)$ & $(0.053)$ & $(0.120)$ & $(0.059)$ & $(0.053)$ & $(0.120)$ & $(0.060)$ & $(0.055)$ \\
\hline \multirow[t]{2}{*}{ Resources for innovation } & 0.045 & 0.035 & -0.025 & 0.017 & $0.145^{*}$ & 0.092 & 0.031 & 0.098 & 0.043 \\
\hline & $(0.144)$ & $(0.080)$ & $(0.059)$ & $(0.146)$ & $(0.081)$ & $(0.058)$ & $(0.147)$ & $(0.080)$ & $(0.063)$ \\
\hline \multirow[t]{2}{*}{ Relative capacity } & $0.371 * * *$ & $0.112^{*}$ & 0.004 & $0.352 * * *$ & 0.082 & 0.040 & $0.361 * * *$ & 0.077 & $0.108^{*}$ \\
\hline & $(0.122)$ & $(0.066)$ & $(0.052)$ & $(0.121)$ & $(0.060)$ & $(0.052)$ & $(0.121)$ & $(0.063)$ & $(0.055)$ \\
\hline \multirow[t]{2}{*}{ R\&D strategy } & $0.419 * * *$ & 0.005 & $0.132 * *$ & $0.418 * * *$ & $0.193 * * *$ & $0.229 * * *$ & $0.425 * * *$ & $0.220 * * *$ & $0.213 * * *$ \\
\hline & $(0.122)$ & $(0.072)$ & $(0.056)$ & $(0.124)$ & $(0.067)$ & $(0.057)$ & $(0.122)$ & $(0.068)$ & $(0.059)$ \\
\hline \multirow[t]{2}{*}{ R\&D department } & $0.309 * *$ & -0.106 & 0.034 & $0.313 * *$ & -0.112 & 0.055 & $0.314 * *$ & 0.027 & -0.048 \\
\hline & $(0.134)$ & $(0.071)$ & $(0.057)$ & $(0.136)$ & $(0.070)$ & $(0.057)$ & $(0.136)$ & $(0.074)$ & $(0.061)$ \\
\hline \multirow[t]{2}{*}{ Small firms } & $0.467 * * *$ & -0.019 & -0.075 & $0.456 * * *$ & 0.070 & 0.005 & $0.460 * * *$ & $-0.146^{* *}$ & 0.028 \\
\hline & $(0.136)$ & $(0.072)$ & $(0.059)$ & $(0.136)$ & $(0.067)$ & $(0.058)$ & $(0.137)$ & $(0.062)$ & $(0.065)$ \\
\hline \multirow[t]{2}{*}{ Medium firms } & $0.327 * *$ & -0.065 & 0.002 & $0.332 * *$ & -0.054 & 0.008 & $0.337 * *$ & -0.105 & -0.062 \\
\hline & $(0.166)$ & $(0.091)$ & $(0.073)$ & $(0.168)$ & $(0.079)$ & $(0.075)$ & $(0.168)$ & $(0.084)$ & $(0.078)$ \\
\hline \multirow[t]{2}{*}{ Tech. park } & 0.042 & -0.068 & -0.017 & 0.050 & 0.004 & -0.043 & 0.051 & 0.007 & 0.041 \\
\hline & $(0.163)$ & $(0.082)$ & $(0.069)$ & $(0.166)$ & $(0.080)$ & $(0.066)$ & $(0.166)$ & $(0.076)$ & $(0.075)$ \\
\hline \multirow[t]{2}{*}{ Tech. platform } & 0.098 & -0.112 & 0.072 & 0.108 & $0.171 * *$ & 0.081 & 0.121 & 0.038 & $0.168 * * *$ \\
\hline & $(0.148)$ & $(0.083)$ & $(0.060)$ & $(0.148)$ & $(0.078)$ & $(0.057)$ & $(0.147)$ & $(0.080)$ & $(0.062)$ \\
\hline \multirow{2}{*}{$\begin{array}{l}\text { Simple reporting } \\
\text { requirements }\end{array}$} & $0.256^{* *}$ & & & $0.273 * *$ & & & $0.279 * *$ & & \\
\hline & $(0.120)$ & & & $(0.122)$ & & & $(0.122)$ & & \\
\hline \multirow{2}{*}{$\begin{array}{l}\text { Adequate marketing of } \\
\text { programmes }\end{array}$} & $-0.330 * *$ & & & $-0.329 * *$ & & & $-0.367 * *$ & & \\
\hline & $(0.141)$ & & & $(0.143)$ & & & $(0.144)$ & & \\
\hline \multirow[t]{2}{*}{ Constant } & $-1.422 * * *$ & $0.454 * * *$ & $0.582 * * *$ & $-1.440 * * *$ & $0.199 * *$ & $0.300 * * *$ & $-1.450 * * *$ & $0.331 * * *$ & $0.259 * *$ \\
\hline & $(0.223)$ & $(0.102)$ & $(0.112)$ & $(0.230)$ & $(0.093)$ & $(0.115)$ & $(0.230)$ & $(0.095)$ & $(0.118)$ \\
\hline
\end{tabular}

Notes: Robust standard errors in parentheses; $* * * p<0.01, * * p<0.05, * p<0.1$. Industry and country dummies are included but not reported. 
Table A4. Results from the copula approach for national R\&D programmes - part 2

\begin{tabular}{|c|c|c|c|c|c|c|}
\hline Independent variables & $\begin{array}{l}\text { Selection } \\
\text { equation }\end{array}$ & $\begin{array}{l}\text { Outcome } \\
\text { equation } \\
\text { regime } 0\end{array}$ & $\begin{array}{l}\text { Outcome } \\
\text { equation } \\
\text { regime } 1\end{array}$ & $\begin{array}{l}\text { Selection } \\
\text { equation }\end{array}$ & $\begin{array}{l}\text { Outcome } \\
\text { equation } \\
\text { regime } 0\end{array}$ & $\begin{array}{l}\text { Outcome } \\
\text { equation } \\
\text { regime } 1\end{array}$ \\
\hline \multirow[t]{2}{*}{ R\&D expenditure } & $0.198 * * *$ & -0.002 & 0.009 & $0.195 * * *$ & 0.021 & 0.018 \\
\hline & $(0.065)$ & $(0.028)$ & $(0.024)$ & $(0.066)$ & $(0.033)$ & $(0.029)$ \\
\hline \multirow[t]{2}{*}{ Export } & 0.184 & 0.009 & 0.022 & 0.181 & $0.088 *$ & -0.096 \\
\hline & $(0.129)$ & $(0.050)$ & $(0.053)$ & $(0.129)$ & $(0.051)$ & $(0.070)$ \\
\hline \multirow[t]{2}{*}{ Competition } & $-0.253 * *$ & 0.043 & 0.054 & $-0.258 * *$ & -0.019 & -0.034 \\
\hline & $(0.120)$ & $(0.049)$ & $(0.047)$ & $(0.119)$ & $(0.054)$ & $(0.056)$ \\
\hline \multirow[t]{2}{*}{ Resources for innovation } & 0.027 & 0.091 & -0.039 & 0.030 & $0.127^{*}$ & -0.021 \\
\hline & $(0.147)$ & $(0.067)$ & $(0.056)$ & $(0.146)$ & $(0.076)$ & $(0.066)$ \\
\hline \multirow[t]{2}{*}{ Relative capacity } & $0.365 * * *$ & $0.132 * *$ & $0.104 * *$ & $0.356 * * *$ & 0.056 & 0.050 \\
\hline & $(0.122)$ & $(0.053)$ & $(0.047)$ & $(0.121)$ & $(0.056)$ & $(0.059)$ \\
\hline \multirow[t]{2}{*}{ R\&D strategy } & $0.426 * * *$ & $0.129 * *$ & 0.034 & $0.412 * * *$ & $0.149 * *$ & 0.034 \\
\hline & $(0.122)$ & $(0.055)$ & $(0.053)$ & $(0.122)$ & $(0.066)$ & $(0.059)$ \\
\hline \multirow[t]{2}{*}{ R\&D department } & $0.325 * *$ & -0.017 & 0.017 & $0.318 * *$ & -0.027 & 0.096 \\
\hline & $(0.137)$ & $(0.060)$ & $(0.055)$ & $(0.134)$ & $(0.068)$ & $(0.064)$ \\
\hline \multirow[t]{2}{*}{ Small firms } & $0.452 * * *$ & -0.087 & $-0.150 * * *$ & $0.466 * * *$ & -0.062 & -0.002 \\
\hline & $(0.139)$ & $(0.053)$ & $(0.055)$ & $(0.136)$ & $(0.062)$ & $(0.063)$ \\
\hline \multirow[t]{2}{*}{ Medium firms } & $0.329^{*}$ & -0.019 & -0.113 & $0.345 * *$ & -0.101 & -0.027 \\
\hline & $(0.171)$ & $(0.073)$ & $(0.071)$ & $(0.167)$ & $(0.068)$ & $(0.082)$ \\
\hline \multirow[t]{2}{*}{ Tech. park } & 0.039 & 0.049 & -0.034 & 0.054 & 0.045 & 0.089 \\
\hline & $(0.169)$ & $(0.072)$ & $(0.066)$ & $(0.166)$ & $(0.080)$ & $(0.072)$ \\
\hline \multirow[t]{2}{*}{ Tech. platform } & 0.131 & 0.064 & $0.100^{*}$ & 0.102 & $0.238 * * *$ & $0.247 * * *$ \\
\hline & $(0.149)$ & $(0.065)$ & $(0.055)$ & $(0.147)$ & $(0.081)$ & $(\cap \cap G)$ \\
\hline \multirow{2}{*}{$\begin{array}{l}\text { Simple reporting } \\
\text { requirements }\end{array}$} & $0.305 * *$ & & & $0.309 * *$ & & \\
\hline & $(0.123)$ & & & $(0.125)$ & & \\
\hline \multirow{2}{*}{$\begin{array}{l}\text { Adequate marketing of } \\
\text { programmes }\end{array}$} & $-0.379 * * *$ & & & $-0.353 * *$ & & \\
\hline & $(0.140)$ & & & $(0.139)$ & & \\
\hline Constant & $\begin{array}{c}-1.421 * * * \\
(0.229)\end{array}$ & $\begin{array}{l}0.131^{*} \\
(0.073)\end{array}$ & $\begin{array}{c}0.389 * * * \\
(0.101)\end{array}$ & $\begin{array}{c}-1.458 * * * \\
(0.232)\end{array}$ & $\begin{array}{c}0.153 * \\
(0.083)\end{array}$ & $\begin{array}{c}0.525^{* * *} * \\
(0.119)\end{array}$ \\
\hline
\end{tabular}

Notes: Robust standard errors in parentheses; $* * * p<0.01, * * p<0.05, * p<0.1$. Industry and country dummies are included but not reported. 
Table A5. Results from the copula approach for international R\&D programmes - part 1

\begin{tabular}{|c|c|c|c|c|c|c|c|c|c|}
\hline Independent variables & $\begin{array}{l}\text { Selection } \\
\text { equation }\end{array}$ & $\begin{array}{l}\text { Outcome } \\
\text { equation } \\
\text { regime } 0 \\
\end{array}$ & $\begin{array}{l}\text { Outcome } \\
\text { equation } \\
\text { regime } 1 \\
\end{array}$ & $\begin{array}{l}\text { Selection } \\
\text { equation }\end{array}$ & $\begin{array}{l}\text { Outcome } \\
\text { equation } \\
\text { regime 0 }\end{array}$ & $\begin{array}{l}\text { Outcome } \\
\text { equation } \\
\text { regime } 1 \\
\end{array}$ & $\begin{array}{l}\text { Selection } \\
\text { equation }\end{array}$ & $\begin{array}{l}\text { Outcome } \\
\text { equation } \\
\text { regime } 0\end{array}$ & $\begin{array}{l}\text { Outcome } \\
\text { equation } \\
\text { regime } 1 \\
\end{array}$ \\
\hline \multirow[t]{2}{*}{ R\&D expenditure } & $0.329 * * *$ & -0.015 & 0.052 & $0.343 * * *$ & 0.012 & -0.010 & $0.341 * * *$ & $0.064 * *$ & -0.019 \\
\hline & $(0.069)$ & $(0.028)$ & $(0.039)$ & $(0.070)$ & $(0.031)$ & $(0.038)$ & $(0.070)$ & $(0.027)$ & $(0.039)$ \\
\hline \multirow[t]{2}{*}{ Export } & $0.370 * * *$ & 0.062 & $0.174 *$ & $0.372 * * *$ & 0.082 & -0.016 & $0.392 * * *$ & 0.052 & 0.013 \\
\hline & $(0.140)$ & $(0.053)$ & $(0.090)$ & $(0.144)$ & $(0.055)$ & $(0.086)$ & $(0.144)$ & $(0.048)$ & $(0.087)$ \\
\hline \multirow[t]{2}{*}{ Competition } & 0.087 & -0.046 & 0.017 & 0.092 & -0.027 & -0.053 & 0.109 & -0.061 & -0.027 \\
\hline & $(0.129)$ & $(0.048)$ & $(0.074)$ & $(0.132)$ & $(0.047)$ & $(0.078)$ & $(0.130)$ & $(0.047)$ & $(0.078)$ \\
\hline \multirow{2}{*}{ Resources for innovation } & $0.369 * *$ & -0.023 & -0.078 & $0.405 * * *$ & 0.094 & 0.021 & $0.368 * *$ & 0.043 & 0.104 \\
\hline & $(0.149)$ & $(0.060)$ & $(0.072)$ & $(0.150)$ & $(0.067)$ & $(0.074)$ & $(0.144)$ & $(0.063)$ & $(0.076)$ \\
\hline \multirow[t]{2}{*}{ Relative capacity } & 0.156 & 0.076 & -0.064 & 0.158 & 0.065 & 0.011 & 0.130 & $0.102 * *$ & 0.048 \\
\hline & $(0.128)$ & $(0.049)$ & $(0.072)$ & $(0.128)$ & $(0.047)$ & $(0.069)$ & $(0.128)$ & $(0.047)$ & $(0.075)$ \\
\hline \multirow[t]{2}{*}{ R\&D strategy } & $0.301 * *$ & $0.114^{* *}$ & -0.007 & $0.277^{*}$ & $0.258 * * *$ & 0.032 & $0.280 * *$ & $0.209 * * *$ & $0.153^{*}$ \\
\hline & $(0.136)$ & $(0.053)$ & $(0.070)$ & $(0.144)$ & $(0.071)$ & $(0.070)$ & $(0.136)$ & $(0.051)$ & $(0.082)$ \\
\hline \multirow[t]{2}{*}{ R\&D department } & -0.185 & -0.005 & 0.053 & -0.221 & 0.010 & 0.032 & -0.202 & -0.062 & 0.107 \\
\hline & $(0.138)$ & $(0.058)$ & $(0.072)$ & $(0.139)$ & $(0.058)$ & $(0.068)$ & $(0.139)$ & $(0.058)$ & $(0.076)$ \\
\hline \multirow[t]{2}{*}{ Small firms } & $0.548 * * *$ & $-0.110^{*}$ & $0.135^{*}$ & $0.624 * * *$ & -0.010 & 0.047 & $0.627 * * *$ & $-0.091 *$ & 0.064 \\
\hline & $(0.154)$ & $(0.059)$ & $(0.076)$ & $(0.148)$ & $(0.061)$ & $(0.072)$ & $(0.148)$ & $(0.053)$ & $(0.087)$ \\
\hline \multirow[t]{2}{*}{ Medium firms } & $0.717 * * *$ & -0.055 & -0.028 & $0.788 * * *$ & -0.080 & -0.046 & $0.762 * * *$ & -0.039 & $-0.260 * *$ \\
\hline & $(0.188)$ & $(0.073)$ & $(0.102)$ & $(0.190)$ & $(0.069)$ & $(0.093)$ & $(0.190)$ & $(0.071)$ & $(0.101)$ \\
\hline \multirow[t]{2}{*}{ Tech. park } & -0.186 & -0.017 & -0.051 & -0.151 & 0.018 & -0.046 & -0.152 & -0.013 & 0.107 \\
\hline & $(0.171)$ & $(0.065)$ & $(0.092)$ & $(0.176)$ & $(0.065)$ & $(0.086)$ & $(0.173)$ & $(0.063)$ & $(0.095)$ \\
\hline \multirow[t]{2}{*}{ Tech. platform } & 0.055 & -0.036 & $0.135^{*}$ & 0.088 & $0.102 *$ & $0.139 * *$ & 0.023 & $0.107^{*}$ & $0.180 * *$ \\
\hline & $(0.150)$ & $(0.062)$ & $(0.072)$ & $(0.152)$ & $(0.062)$ & $(0.064)$ & $(0.152)$ & $(0.064)$ & $(0.077)$ \\
\hline \multirow{2}{*}{$\begin{array}{l}\text { Transparent evaluation } \\
\text { procedures }\end{array}$} & $0.301 * *$ & & & $0.333 * *$ & & & $0.341 * * *$ & & \\
\hline & $(0.130)$ & & & $(0.135)$ & & & $(0.127)$ & & \\
\hline \multirow{2}{*}{$\begin{array}{l}\text { Adequate networks of } \\
\text { potential partners }\end{array}$} & $0.524 * * *$ & & & $0.454 * * *$ & & & $0.419 * * *$ & & \\
\hline & $(0.142)$ & & & $(0.147)$ & & & $(0.141)$ & & \\
\hline $\begin{array}{l}\text { Adequate marketing of } \\
\text { programmes }\end{array}$ & $-0.580 * * *$ & & & $-0.653 * * *$ & & & $-0.614 * * *$ & & \\
\hline & $(0.159)$ & & & $(0.157)$ & & & $(0.154)$ & & \\
\hline Constant & $\begin{array}{c}-2.039 * * * \\
(0.276)\end{array}$ & $\begin{array}{c}0.541 * * * \\
(0.090)\end{array}$ & $\begin{array}{l}0.372 * * \\
(0.162)\end{array}$ & $\begin{array}{c}-2.179 * * * \\
(0.278)\end{array}$ & $\begin{array}{l}0.190 * * \\
(0.079)\end{array}$ & $\begin{array}{c}0.715 * * * \\
(0.145)\end{array}$ & $\begin{array}{c}-2.111 * * * \\
(0.279)\end{array}$ & $\begin{array}{c}0.304 * * * \\
(0.087)\end{array}$ & $\begin{array}{l}0.284^{*} \\
(0.152)\end{array}$ \\
\hline
\end{tabular}

Notes: Robust standard errors in parentheses; ${ }^{* * *} p<0.01,{ }^{* *} p<0.05,{ }^{*} p<0.1$. Industry and country dummies are included but not reported. 
Table A6. Results from the copula approach for international R\&D programmes - part 2

\begin{tabular}{|c|c|c|c|c|c|c|}
\hline Independent variables & $\begin{array}{l}\text { Selection } \\
\text { equation }\end{array}$ & $\begin{array}{l}\text { Outcome } \\
\text { equation } \\
\text { regime } 0\end{array}$ & $\begin{array}{l}\text { Outcome } \\
\text { equation } \\
\text { regime } 1\end{array}$ & $\begin{array}{l}\text { Selection } \\
\text { equation }\end{array}$ & $\begin{array}{l}\text { Outcome } \\
\text { equation } \\
\text { regime } 0\end{array}$ & $\begin{array}{l}\text { Outcome } \\
\text { equation } \\
\text { regime 1 }\end{array}$ \\
\hline \multirow[t]{2}{*}{ R\&D expenditure } & $0.338 * * *$ & 0.033 & -0.026 & $0.332 * * *$ & $0.062 * *$ & -0.031 \\
\hline & $(0.069)$ & $(0.022)$ & $(0.034)$ & $(0.069)$ & $(0.027)$ & $(0.042)$ \\
\hline \multirow[t]{2}{*}{ Export } & $0.387 * * *$ & 0.031 & 0.007 & $0.376^{* * *}$ & 0.053 & -0.107 \\
\hline & $(0.142)$ & $(0.042)$ & $(0.076)$ & $(0.142)$ & $(0.048)$ & $(0.096)$ \\
\hline \multirow[t]{2}{*}{ Competition } & 0.100 & $0.084^{* *}$ & -0.010 & 0.108 & -0.044 & -0.023 \\
\hline & $(0.128)$ & $(0.039)$ & $(0.071)$ & $(0.128)$ & $(0.045)$ & $(0.079)$ \\
\hline \multirow[t]{2}{*}{ Resources for innovation } & $0.367 * *$ & 0.041 & -0.034 & $0.372 * *$ & 0.068 & 0.033 \\
\hline & $(0.143)$ & $(0.056)$ & $(0.073)$ & $(0.145)$ & $(0.060)$ & $(0.084)$ \\
\hline \multirow{2}{*}{ Relative capacity } & 0.127 & $0.134 * * *$ & 0.096 & 0.132 & $0.096 * *$ & 0.019 \\
\hline & $(0.129)$ & $(0.042)$ & $(0.069)$ & $(0.129)$ & $(0.045)$ & $(0.077)$ \\
\hline \multirow[t]{2}{*}{ R\&D strategy } & $0.284 * *$ & $0.138 * * *$ & -0.030 & $0.295 * *$ & 0.061 & 0.059 \\
\hline & $(0.135)$ & $(0.045)$ & $(0.075)$ & $(0.135)$ & $(0.052)$ & $(0.080)$ \\
\hline \multirow[t]{2}{*}{ R\&D department } & -0.199 & -0.044 & 0.091 & -0.202 & 0.008 & $0.164 * *$ \\
\hline & $(0.139)$ & $(0.050)$ & $(0.071)$ & $(0.139)$ & $(0.058)$ & $(0.080)$ \\
\hline \multirow[t]{2}{*}{ Small firms } & $0.642 * * *$ & $-0.116^{* * *}$ & -0.044 & $0.615^{* * *}$ & -0.067 & 0.063 \\
\hline & $(0.145)$ & $(0.044)$ & $(0.079)$ & $(0.146)$ & $(0.050)$ & $(0.089)$ \\
\hline \multirow[t]{2}{*}{ Medium firms } & $0.756 * * *$ & -0.036 & $-0.166 * *$ & $0.742 * * *$ & -0.037 & -0.127 \\
\hline & $(0.191)$ & $(0.063)$ & $(0.082)$ & $(0.191)$ & $(0.070)$ & (0.099) \\
\hline \multirow[t]{2}{*}{ Tech. park } & -0.147 & 0.016 & -0.033 & -0.151 & 0.036 & 0.123 \\
\hline & $(0.171)$ & $(0.058)$ & $(0.085)$ & $(0.170)$ & $(0.063)$ & $(0.096)$ \\
\hline \multirow[t]{2}{*}{ Tech. platform } & 0.019 & 0.047 & $0.154 * *$ & 0.017 & $0.272 * * *$ & $0.276^{* * *}$ \\
\hline & $(0.152)$ & $(0.052)$ & $(0.076)$ & $(0.152)$ & $(0.064)$ & $(0.075)$ \\
\hline Transparent evaluation procedures & $\begin{array}{c}0.310^{* *} \\
(0.131)\end{array}$ & & & $\begin{array}{c}0.377 * * * \\
(0.126)\end{array}$ & & \\
\hline \multirow{2}{*}{$\begin{array}{l}\text { Adequate networks of potential } \\
\text { partners }\end{array}$} & $0.385 * * *$ & & & $0.372 * *$ & & \\
\hline & $(0.143)$ & & & $(0.145)$ & & \\
\hline \multirow[t]{2}{*}{$\begin{array}{l}\text { Adequate marketing of } \\
\text { programmes }\end{array}$} & $-0.585^{* * *}$ & & & $-0.643 * * *$ & & \\
\hline & $(0.157)$ & & & $(0.153)$ & & \\
\hline Constant & $\begin{array}{l}-2.094 * * * \\
(0.279)\end{array}$ & $\begin{array}{c}0.109 \\
(0.067)\end{array}$ & $\begin{array}{l}0.320 * * \\
(0.139)\end{array}$ & $\begin{array}{c}-2.099 * * * \\
(0.281)\end{array}$ & $\begin{array}{l}0.161^{* *} \\
(0.079)\end{array}$ & $\begin{array}{c}0.594 * * * \\
(0.162)\end{array}$ \\
\hline
\end{tabular}

Notes: Robust standard errors in parentheses; $* * * p<0.01, * * p<0.05, * p<0.1$. Industry and country dummies are included but not reported. 